\title{
Review \\ Toward Eco-Friendly Dye-Sensitized Solar Cells (DSSCs): Natural Dyes and Aqueous Electrolytes
}

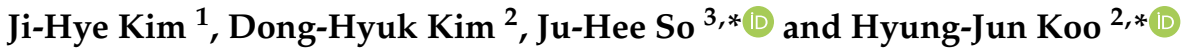 \\ 1 Department of New Energy Engineering, Seoul National University of Science and Technology, \\ 232 Gongneung-ro, Nowon-gu, Seoul 01811, Korea; gh5289@naver.com \\ 2 Department of Chemical and Biomolecular Engineering, Seoul National University of Science and Technology, \\ 232 Gongneung-ro, Nowon-gu, Seoul 01811, Korea; dongh4474@naver.com \\ 3 Material \& Component Convergence R\&D Department, Korea Institute of Industrial Technology, \\ Ansan 15588, Korea \\ * Correspondence: jso@kitech.re.kr (J.-H.S.); hjkoo@seoultech.ac.kr (H.-J.K.)
}

check for updates

Citation: Kim, J.-H.; Kim, D.-H.; So, J.-H.; Koo, H.-J. Toward Eco-Friendly Dye-Sensitized Solar Cells (DSSCs):

Natural Dyes and Aqueous

Electrolytes. Energies 2022, 15, 219.

https://doi.org/10.3390/en15010219

Academic Editors: Yasemin Saygili and Audun Formo Buene

Received: 28 November 2021

Accepted: 27 December 2021

Published: 29 December 2021

Publisher's Note: MDPI stays neutral with regard to jurisdictional claims in published maps and institutional affiliations.

Copyright: (C) 2021 by the authors. Licensee MDPI, Basel, Switzerland. This article is an open access article distributed under the terms and conditions of the Creative Commons Attribution (CC BY) license (https:// creativecommons.org/licenses/by/ $4.0 /)$.

\begin{abstract}
Due to their low cost, facile fabrication, and high-power conversion efficiency (PCE), dyesensitized solar cells (DSSCs) have attracted much attention. Ruthenium (Ru) complex dyes and organic solvent-based electrolytes are typically used in high-efficiency DSSCs. However, Ru dyes are expensive and require a complex synthesis process. Organic solvents are toxic, environmentally hazardous, and explosive, and can cause leakage problems due to their low surface tension. This review summarizes and discusses previous works to replace them with natural dyes and water-based electrolytes to fabricate low-cost, safe, biocompatible, and environmentally friendly DSSCs. Although the performance of "eco-friendly DSSCs" remains less than 1\%, continuous efforts to improve the PCE can accelerate the development of more practical devices, such as designing novel redox couples and photosensitizers, interfacial engineering of photoanodes and electrolytes, and biomimetic approaches inspired by natural systems.
\end{abstract}

Keywords: dye sensitized solar cells (DSSCs); natural dye; aqueous electrolyte; eco-friendly DSSCs

\section{Introduction}

Since the late 19th century, renewable energy resources, such as solar, hydropower, geothermal, biomass, and biofuel energy, have attracted much attention to substitute fossil fuel, the main cause of global warming [1]. Solar energy is a limitless energy source without the emission of $\mathrm{CO}_{2}$, which accounts for a large portion of greenhouse gas. Solar energy can be converted into other types of energy by photovoltaic or photothermal mechanisms [2-4]. A solar cell utilizes solar energy by converting sunlight into electricity based on the photovoltaic mechanism. While a silicon solar cell is the representative one, other types of cells, such as organic solar cells, thin-film solar cells, dye-sensitized solar cells (DSSCs), and perovskite solar cells, have also been studied as economical alternatives [5-7]. DSSCs are one of the third-generation photovoltaic devices suggested as an alternative to conventional Si-based solar cells. DSSCs have various advantages, such as a low cost and robust fabrication process, reasonable power conversion efficiency (PCE), and semitransparency [8,9]. The color of the photoanode can be varied using different dyes adsorbed on it. Additionally, DSSCs operate efficiently even under low-light intensity, enabling them to be used indoors.

DSSCs are composed of a transparent electrode, a photoanode, a dye sensitizer, an electrolyte, and a counter electrode. In 1991, Brian O'Regan and Michael Grätzel reported DSSCs with a high PCE of $7.12 \%$, based on a transparent nanoporous film of titanium dioxide $\left(\mathrm{TiO}_{2}\right)$ and ruthenium $(\mathrm{Ru})$ complex dye [10]. Since then, researchers have developed novel dyes, electrolytes, photoanodes, and counter electrodes, to further improve the efficiency of DSSCs. Recently, a high PCE of $14.34 \%$ was attained by Kakiage et al. via the 
co-sensitization of alkoxysilyl-anchor dye (ADEKA-1) and a carboxy-anchor organic dye (LEG4) using various co-adsorbents with a $\left(\mathrm{Co}(\mathrm{phen})_{3}\right)^{2+/ 3+}$ (phen $=1,10$-phenanthroline) redox electrolyte [11]. Concerning tandem-type cells, Eom et al. reported a high PCE value of $14.64 \%$ in a tandem cell structure, where alkylated thieno(3,2-b)indole-based organic dye (SGT-137) and Zn(II)-porphyrin dye (SGT-021) with a $\left(\mathrm{Co}(\mathrm{bpy})_{3}\right)^{2+/ 3+}$ redox electrolyte were used [12]. For high-efficiency DSSCs, Ru-complexes and organic solvents are mainly used as dyes and electrolyte solvents, respectively. However, Ru-complex dyes are expensive and synthesized via complicated synthesis processes $[13,14]$. Ru compounds are treated as moderately toxic, environmentally hazardous, and carcinogenic. Moreover, organic solvents are generally toxic and explosive and cause environmental problems [15-17]. Ironically, DSSCs that mimic photosynthesis in natural leaves to produce energy are made of materials that could be harmful to nature. Because of these problems, researchers are making efforts to increase efficiency and develop more environmentally friendly DSSCs.

Herein, we review various efforts to fabricate DSSCs based on eco-friendly components, such as natural photosensitizers and water-based electrolytes. First, the harmful effect of typical high-efficient DSSCs on the environment is discussed. Next, we discuss recent research to employ natural dyes derived from nature and aqueous electrolytes in DSSCs. Finally, the example studies of DSSCs fully based on environmentally benign dyes and electrolytes are discussed.

\section{Problems or Harmful Effects}

For high-efficiency DSSCs, Ru-complex dyes and organic solvent-based electrolytes are typically used. However, due to some issues in terms of possible human toxicity, potential environmental impact, production cost, stability, and safety, they are unfavorable and may need to be replaced with other materials.

For high-efficiency DSSCs, electrolytes with low viscosity, high dielectric constant, good solubility, and high chemical stability are required [18-20]. Various solvents have been used for DSSCs. Table 1 presents the melting point, boiling point, vapor pressure $(P)$, and viscosity $(\eta)$ of organic solvents popularly used. Nitrile-based solvents, such as acetonitrile $(\mathrm{ACN})$ and 3-methoxypropionitrile (MPN), are considered the most preferred solvents for electrolytes. Ethylene carbonate (EC), propylene carbonate (PC), $\gamma$-butyrolactone (GBL), and N-methyl-2-pyrrolidone (NMP) are also used due to their low vapor pressure and volatility. However, such organic solvents are not the best choice in terms of safety [19]. $\mathrm{ACN}$ can be metabolized to produce hydrogen cyanide, which is the source of the observed toxic effects in microsomes, especially in the liver [21,22]. EC is converted into ethylene gly$\mathrm{col}$, which is toxic alcohol, causing metabolic acidosis during ingestion [23,24]. GBL is the precursor of $\gamma$-hydroxybutyrate (GHB), which can affect the central nervous system [25,26]. Additionally, some organic solvents have low viscosity, resulting in easy electrolyte leakage and high flammability. Regarding health issues, a high volatility at room temperature causes absorption into the human body due to the high exposure possibility to the solvents. Thus, the solvents are unsuitable given the fabrication of DSSCs that are safe for humans and the environment.

Table 1. Melting point, boiling point, vapor pressure, and viscosity of organic solvents popularly used. All parameter values at $25^{\circ} \mathrm{C}$ unless otherwise indicated.

\begin{tabular}{|c|c|c|c|c|}
\hline Organic Solvent & Melting Point $\left({ }^{\circ} \mathrm{C}\right)$ & Boiling Point $\left({ }^{\circ} \mathrm{C}\right)$ & $\begin{array}{l}\text { Vapor Pressure } \\
\left(\text { Torr, at } 25^{\circ} \mathrm{C}\right)\end{array}$ & $\begin{array}{c}\text { Viscosity } \\
\left.\text { (cP, at } 25^{\circ} \mathrm{C}\right)\end{array}$ \\
\hline Acetonitrile (ACN) & -45 & 81.6 & 88.8 & 0.334 \\
\hline 3-methoxypropionitrile (MPN) & -62.9 & 164 & $1.72\left(30^{\circ} \mathrm{C}\right)$ & 2.5 \\
\hline Valerontrile & -96 & 139 & 2.794 & $0.78\left(19^{\circ} \mathrm{C}\right)$ \\
\hline 3-methyl-2-oxazolidinone (NMO) & 15 & 88 & 0.00877 & 2.5 \\
\hline Ethylene carbonate (EC) & 36 & 238 & 0.0098 & 90 \\
\hline Propylene carbonate (PC) & -49 & 241 & 0.058 & 2.5 \\
\hline$\gamma$-butyrolactone (GBL) & -44 & 204 & $0.45\left(20^{\circ} \mathrm{C}\right)$ & 1.7 \\
\hline N-methyl-2-pyrrolidone (NMP) & -24 & 203 & 0.342 & 1.65 \\
\hline
\end{tabular}


In DSSCs, the dye sensitizer plays a crucial role in absorbing light and converting it into electricity. For high PCE, having a wide range of absorption wavelengths in visible light is important. Ru-complex dyes absorb a wide range of absorption wavelength from $300 \mathrm{~nm}$ to $600 \mathrm{~nm}$ in visible light, resulting in high-efficiency DSSCs with the maximum efficiency of $11.18 \%[27,28]$. The Ru-complex dyes, such as N719, N3, and black dye, are the most widely used due to their long-excited lifetime, wide absorption wavelength, and highly efficient metal-to-ligand charge transfer, despite their low molar extinction coefficients [29-33]. However, Ru-complex dyes are expensive, need sophisticated and complex syntheses processes $[13,14]$, and cause environmental problems, which could be problems to be used in cost-effective and eco-friendly DSSCs. Although Ru is nontoxic, its compounds, such as ruthenium oxide $\left(\mathrm{RuO}_{4}\right)$, are highly toxic and volatile [34-36]. Materials that undergo dye synthesis processes are also harmful to health and cause environmental pollution. For example, ammonium thiocyanate and hydrochloric acid are harmful to health, have high causticity, and generate chlorine [37]. Recently, metal-free organic dyes were developed to replace Ru-based dyes, but organic dyes could be toxic and carcinogenic and produce hazardous pollutants during their synthesis $[38,39]$. All in all, the typical components in DSSCs, organic solvents, and Ru-based complex dyes may need to be replaced to realize low cost, biocompatible, and environmentally benign devices. Water and natural dyes derived from plants could be excellent alternatives.

\section{Natural Dyes Extracted from Nature}

Natural photosensitizers are extracted from parts of plants, such as leaves, fruits, and flowers. The dyes contain anthocyanin, chlorophyll, carotenoid, and betalain. The molecular structures of the natural dyes are shown in Figure 1. Anthocyanins are generally obtained from petals of flowers and fruits and absorb 450-580 nm wavelength of visible light with a maximum peak at the $520 \mathrm{~nm}$ region [40-43]. Anthocyanins contain carbonyl (-CO-) and hydroxyl $(-\mathrm{OH})$ groups. The functional groups enable the molecules to be stably bound to the surface of $\mathrm{TiO}_{2}$, which facilitates electron injection from anthocyanin molecules to the conduction band of $\mathrm{TiO}_{2}$ [44-47]. Chlorophyll, a key molecule in photosynthesis, is a green pigment commonly found in green leaves and plants. Chlorophyll absorbs $400-450$ and 640-680 $\mathrm{nm}$ wavelength of visible light and has a maximum peak at $430 \mathrm{~nm}[48,49]$. Carotenoids are yellow, orange, and red pigments obtained from colored vegetables, plants, and algae. Betalains are yellow and red pigments obtained from petals of flowers, fruits, leaves, and roots of plants. The process of extracting natural dye is simple and possibly environmentally friendly. Therefore, many studies have been actively performed to adopt the natural dyes as a photosensitizer of DSSCs to realize eco-friendly DSSCs.
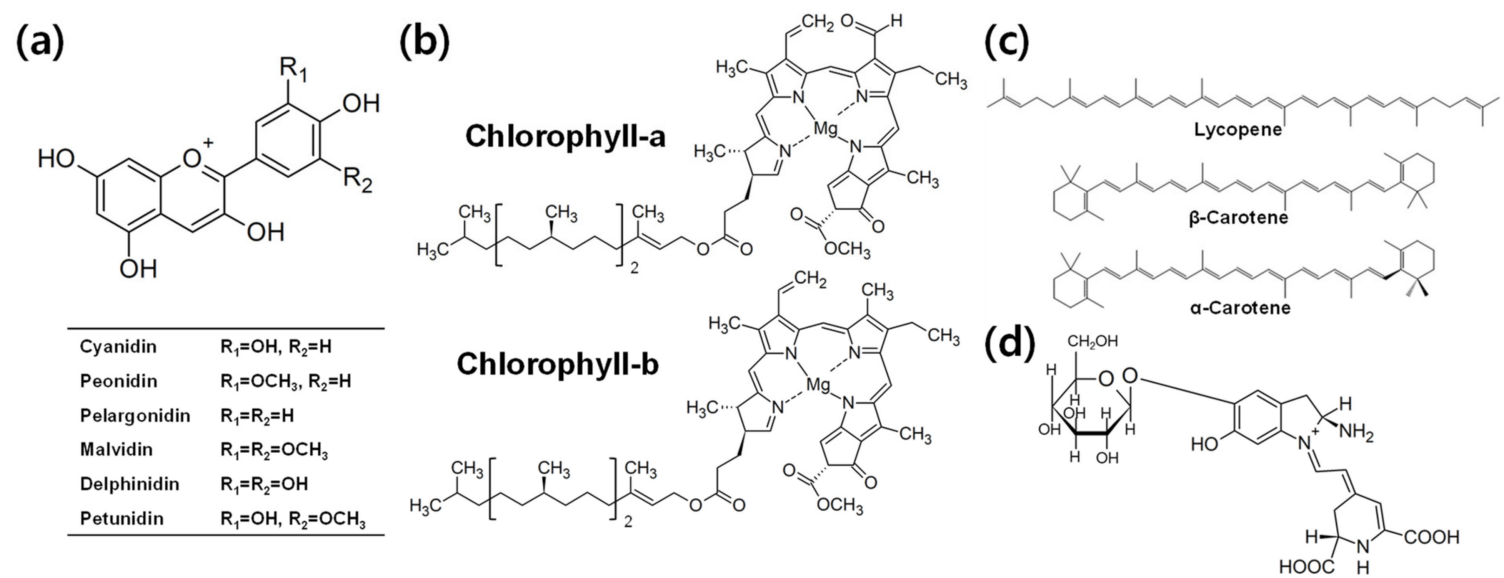

Figure 1. Chemical structures of (a) anthocyanins, (b) chlorophylls, (c) carotenoids, and (d) betalain, reprinted with permission from [50]. Copyright 2019 Springer Nature. 
Table 2 summarizes the previous works on DSSCs based on natural dyes, including the types and sources of naturally derived dyes, materials for photoanodes, electrolytes, and cathodes, and their PCE. Compared to those based on organic or metal-based dyes, DSSCs based on natural dyes exhibited low PCE (mostly $<1 \%$ ). One of the main reasons is that natural dyes absorb a narrow range of light, which inhibits the increase in PCE, whereas organic and rare metal-based dyes have a broad absorption spectrum of visible light $[27,28]$.

Table 2. Types and sources of natural dyes, photoanodes, electrolytes, and cathodes used for the natural dye based-DSSCs and their corresponding photovoltaic performance.

\begin{tabular}{|c|c|c|c|c|c|c|}
\hline Natural Dye & Dye Sources & Photoanode & Electrolyte & Cathode & PCE (\%) & Ref. \\
\hline \multirow{15}{*}{ Chlorophyll } & Spinach & $\mathrm{TiO}_{2}$ treated with $\mathrm{TiCl}_{4}$ & $\mathrm{I}^{-} / \mathrm{I}_{3}^{-}$in $\mathrm{EG}$ & Carbon & 0.56 & [51] \\
\hline & Spinach & $\mathrm{TiO}_{2}$ & $\mathrm{I}^{-} / \mathrm{I}_{3}^{-}$in $\mathrm{EG}$ & Graphite & 0.398 & [52] \\
\hline & Spinach & $\mathrm{ZnO}$ & $\mathrm{I}^{-} / \mathrm{I}_{3}^{-}$ & Carbon & 0.1312 & [49] \\
\hline & Spinach & $\mathrm{TiO}_{2}$ & $\mathrm{I}^{-} / \mathrm{I}_{3}^{-}$ & Graphite & 0.49 & [53] \\
\hline & Spinach & $\mathrm{TiO}_{2}$ & $\mathrm{I}^{-} / \mathrm{I}_{3}^{-}$in $\mathrm{ACN}$ & $\mathrm{Pt}$ & 0.29 & [54] \\
\hline & Spinach & $\mathrm{TiO}_{2}$ & $\mathrm{I}^{-} / \mathrm{I}_{3}^{-}$ & $\mathrm{Pt}$ & 0.1712 & [55] \\
\hline & Neem & $\mathrm{ZnO}$ & $\begin{array}{l}\mathrm{I}^{-} / \mathrm{I}_{3}^{-} \text {in } \\
\mathrm{EG} / \mathrm{ACN}\end{array}$ & Stainless foil & 0.13 & [56] \\
\hline & Wormwood & $\mathrm{TiO}_{2}$ & $\mathrm{I}^{-} / \mathrm{I}_{3}^{-}$in $\mathrm{ACN}$ & $\mathrm{Pt}$ & 0.538 & [29] \\
\hline & Ipomoea & $\mathrm{TiO}_{2}$ & $\mathrm{I}^{-} / \mathrm{I}_{3}^{-}$ & $\mathrm{Pt}$ & 0.278 & [57] \\
\hline & Lemon leaves & $\mathrm{TiO}_{2}$ & $\mathrm{I}^{-} / \mathrm{I}_{3}^{-}$in $\mathrm{ACN}$ & $\mathrm{Pt}$ & 0.04 & [41] \\
\hline & Papaya leaves & $\mathrm{TiO}_{2}$ & $\mathrm{I}^{-} / \mathrm{I}_{3}^{-}$in $\mathrm{ACN}$ & $\mathrm{Pt}$ & 0.07 & [58] \\
\hline & Bermuda grass & $\mathrm{TiO}_{2}$ & $\begin{array}{c}\mathrm{I}^{-} / \mathrm{I}_{3}^{-} \text {in } \\
\mathrm{t}-\mathrm{BuOH} / \mathrm{ACN}\end{array}$ & $\mathrm{Pt}$ & 0.113 & [59] \\
\hline & Papaya peels & $\mathrm{ZnO}$ & $\mathrm{I}^{-} / \mathrm{I}_{3}^{-}$ & FTO & 0.017 & [60] \\
\hline & Pandan leaves & $\mathrm{TiO}_{2}$ & NaI in PVDF-HFP & $\mathrm{Pt}$ & 0.51 & [61] \\
\hline & Pterocarpus Indicus Willd & $\mathrm{TiO}_{2}$ & $\mathrm{I}^{-} / \mathrm{I}_{3}^{-}$in EG & Carbon & 0.0232 & [62] \\
\hline \multirow{23}{*}{ Anthocyanin } & Melinjo skin & $\mathrm{TiO}_{2}$ & $\mathrm{I}^{-} / \mathrm{I}_{3}^{-}$ & $\mathrm{Pt}$ & 0.036 & [63] \\
\hline & Purple cabbage & $\mathrm{ZnO}$ & $\mathrm{I}^{-} / \mathrm{I}_{3}^{-}$ & Carbon & 0.102 & [64] \\
\hline & Purple cabbage & $\mathrm{ZnO}$ & $\mathrm{I}^{-} / \mathrm{I}_{3}^{-}$ & Carbon & 0.1015 & [49] \\
\hline & Siahkooti peel & $\mathrm{TiO}_{2}$ & $\mathrm{I}^{-} / \mathrm{I}_{3}^{-}$in $\mathrm{ACN}$ & $\mathrm{Pt}$ & 0.32 & [45] \\
\hline & Raspberries & $\mathrm{TiO}_{2}$ & $\mathrm{I}^{-} / \mathrm{I}_{3}^{-}$in $\mathrm{ACN}$ & $\mathrm{Pt}$ & 1.5 & [41] \\
\hline & Mangosteen peel & $\mathrm{TiO}_{2}$ treated with $\mathrm{TiCl}_{4}$ & $\mathrm{~T}_{2} / \mathrm{T}^{-}$in $\mathrm{ACN}$ & $\begin{array}{l}\text { Mangosteen peel } \\
\text { carbon (MPC) }\end{array}$ & 2.63 & [65] \\
\hline & Dragon fruit & $\mathrm{TiO}_{2}$ & $\mathrm{I}^{-} / \mathrm{I}_{3}^{-}$ & $\mathrm{Pt}$ & 0.22 & [66] \\
\hline & Cumini & $\mathrm{TiO}_{2}$ & $\begin{array}{l}\mathrm{I}^{-} / \mathrm{I}_{3}^{-} \text {in } \\
\text { PEO:PEG }\end{array}$ & $\mathrm{Pt}$ & 0.07 & [67] \\
\hline & Pomegranate & $\mathrm{TiO}_{2}$ & $\begin{array}{c}\mathrm{I}^{-} / \mathrm{I}_{3}^{-}: \text {PEG in } \\
\mathrm{ACN}\end{array}$ & $\mathrm{Pt}$ & 0.028 & [68] \\
\hline & Red cabbage & $\mathrm{TiO}_{2}$ & $\mathrm{I}^{-} / \mathrm{I}_{3}^{-}$in PEG & Carbon & 0.024 & [40] \\
\hline & Fistula flower & $\mathrm{TiO}_{2}$ & $\mathrm{I}^{-} / \mathrm{I}_{3}^{-}$in $\mathrm{ACN}$ & $\mathrm{Pt}$ & 0.21 & [69] \\
\hline & Rhododendron flower (red) & $\mathrm{TiO}_{2}$ & $\mathrm{I}^{-} / \mathrm{I}_{3}^{-}$ & $\mathrm{Pt}$ & 0.33 & [70] \\
\hline & Canarium odontophyllum & $\mathrm{TiO}_{2}$ & $\begin{array}{l}\mathrm{I}^{-} / \mathrm{I}_{3}{ }^{-} \text {in } \\
\mathrm{EG} / \mathrm{ACN}\end{array}$ & $\mathrm{Pt}$ & 0.96 & [42] \\
\hline & Areca catechu & $\mathrm{TiO}_{2}$ & $\mathrm{I}^{-} / \mathrm{I}_{3}^{-}$ & $\mathrm{Pt}$ & 0.38 & [71] \\
\hline & Pomegranate & $\mathrm{TiO}_{2}-\mathrm{WO}_{3}$ & $\begin{array}{l}\mathrm{I}^{-} / \mathrm{I}_{3}{ }^{-} \text {in } \\
\text { chitosan }\end{array}$ & $\mathrm{Pt}$ & 1.8 & [72] \\
\hline & Mangosteen peel & $\mathrm{TiO}_{2}$ & $\mathrm{I}^{-} / \mathrm{I}_{3}^{-}$ & $\mathrm{Pt}$ & 0.199 & [73] \\
\hline & Black rice & $\mathrm{TiO}_{2}$ & $\mathrm{NaI}$ in PVDF-HFP & $\mathrm{Pt}$ & 0.56 & [61] \\
\hline & Rosella & $\mathrm{TiO}_{2}$ & $\mathrm{I}^{-} / \mathrm{I}_{3}^{-}$in $\mathrm{EG}$ & $\mathrm{Pt}$ & 0.37 & [43] \\
\hline & Onion peel & $\mathrm{TiO}_{2}$ & $\mathrm{I}^{-} / \mathrm{I}_{3}^{-}$ & $\mathrm{Pt}$ & 0.0647 & [55] \\
\hline & $\begin{array}{l}\text { Acanthus sennii chiovenda } \\
\text { flower }\end{array}$ & $\mathrm{TiO}_{2}$ & $\begin{array}{l}\mathrm{I}^{-} / \mathrm{I}_{3}^{-} \text {in gel } \\
\text { electrolyte }\end{array}$ & PEDOT & 0.15 & [74] \\
\hline & Consolida jacis & $\mathrm{TiO}_{2}$ & $\begin{array}{l}\mathrm{I}^{-} / \mathrm{I}_{3}^{-} \text {in } \\
\mathrm{ACN} / \mathrm{VN}\end{array}$ & Steel mesh & 0.6 & [75] \\
\hline & Petals of lxora coccinea & $\mathrm{TiO}_{2}$ & $\begin{array}{l}\mathrm{I}^{-} / \mathrm{I}_{3}^{-} \text {in } \\
\mathrm{ACN} / \mathrm{EC}\end{array}$ & $\mathrm{Pt}$ & 0.76 & [76] \\
\hline & Blueberry & $\mathrm{TiO}_{2}$ & $\mathrm{I}^{-} / \mathrm{I}_{3}^{-}$ & $\mathrm{Pt}$ & 0.69 & [77] \\
\hline
\end{tabular}


Table 2. Cont.

\begin{tabular}{|c|c|c|c|c|c|c|}
\hline Natural Dye & Dye Sources & Photoanode & Electrolyte & Cathode & PCE (\%) & Ref. \\
\hline \multirow{8}{*}{ Betalain } & Cactus & $\mathrm{TiO}_{2}$ & $\begin{array}{c}\mathrm{I}^{-} / \mathrm{I}_{3}^{-} \text {in } \\
\mathrm{t}-\mathrm{BuOH} / \mathrm{ACN}\end{array}$ & $\mathrm{Pt}$ & 0.674 & [59] \\
\hline & Yellow sweet potato & $\mathrm{TiO}_{2}$ & $\mathrm{I}^{-} / \mathrm{I}_{3}^{-}$ & $\mathrm{Pt}$ & 0.057 & [63] \\
\hline & Beetroot & $\mathrm{TiO}_{2}$ treated with $\mathrm{TiCl}_{4}$ & $\mathrm{I}^{-} / \mathrm{I}_{3}^{-}$in $\mathrm{EG}$ & Carbon & 0.49 & [51] \\
\hline & Beetroot & $\mathrm{ZnO}$ & $\mathrm{I}^{-} / \mathrm{I}_{3}^{-}$ & Carbon & 0.179 & [64] \\
\hline & Beetroot & $\mathrm{TiO}_{2}$ & $\begin{array}{l}\mathrm{I}^{-} / \mathrm{I}_{3}^{-} \text {in } \\
\mathrm{ACN} / \mathrm{EC}\end{array}$ & Graphite & 1.3 & [78] \\
\hline & Turmeric stem & $\mathrm{ZnO}$ & $\mathrm{I}^{-} / \mathrm{I}_{3}^{-}$ & Carbon & 0.3045 & [79] \\
\hline & Turmeric & $\mathrm{TiO}_{2}$ & $\mathrm{I}^{-} / \mathrm{I}_{3}{ }^{-}$in $\mathrm{EG}$ & Carbon & 0.33 & [80] \\
\hline & Bougainvillea spectabilis & $\mathrm{TiO}_{2}$ & $\begin{array}{l}\mathrm{I}^{-} / \mathrm{I}_{3}^{-} \text {in } \\
\mathrm{ACN} / \mathrm{EC}\end{array}$ & $\mathrm{Pt}$ & 0.21 & [76] \\
\hline \multirow{2}{*}{ Lawsone } & Lawsonia inermis & $\mathrm{TiO}_{2}$ & $\mathrm{I}^{-} / \mathrm{I}_{3}^{-}$ & $\mathrm{Pt}$ & 1.47 & [81] \\
\hline & Henna leaves & $\mathrm{TiO}_{2}$ & $\mathrm{I}^{-} / \mathrm{I}_{3}^{-}$in $\mathrm{ACN}$ & Graphite & 1.08 & [78] \\
\hline Carotenoid & Orange peel & $\mathrm{TiO}_{2}$ & $\begin{array}{c}\mathrm{I}^{-} / \mathrm{I}_{3}^{-}: \text {PEG in } \\
\text { ACN }\end{array}$ & $\mathrm{Pt}$ & 0.005 & [68] \\
\hline Curcumin & Turmeric root & $\mathrm{TiO}_{2}$ & $\mathrm{I}^{-} / \mathrm{I}_{3}^{-}$in $\mathrm{EG}$ & Carbon & 0.11 & [82] \\
\hline Indigo & Indigofera tinctoria & $\mathrm{TiO}_{2}$ treated with $\mathrm{TiCl}_{4}$ & $\mathrm{I}^{-} / \mathrm{I}_{3}^{-}$in MPN & $\mathrm{Pt}$ & 0.114 & [14] \\
\hline
\end{tabular}

The condition of natural dyes and concentration of dye extract solutions are affected by the extraction temperature, $\mathrm{pH}$, and the types of solvents. For example, high temperatures can thermally degrade dyes, whereas low temperatures can limit the solubility of dyes in extracting solvents [43]. Moreover, dyes have different solubilities depending on the types of solvents because the molecules of natural dyes have different polarities [71,83,84]. Figure 2a shows the absorbance of anthocyanin extracted from Areca catech $u$ according to different extracting solvents [71]. Wongcharee et al. investigated the effect of the types of extracting solvents on the efficiency of the resulting DSSCs [43]. It has been reported that although anthocyanin is more soluble in ethanol than water, the photocatalytic decomposition by $\mathrm{TiO}_{2}$ occurred in the presence of ethanol, decreasing the efficiency after being exposed to sunlight for some time. It has been concluded that ethanol is unsuitable as an anthocyanin-extracting solvent. Thus, the appropriate choice of extracting solvents is important in the dye extraction process.

(a)

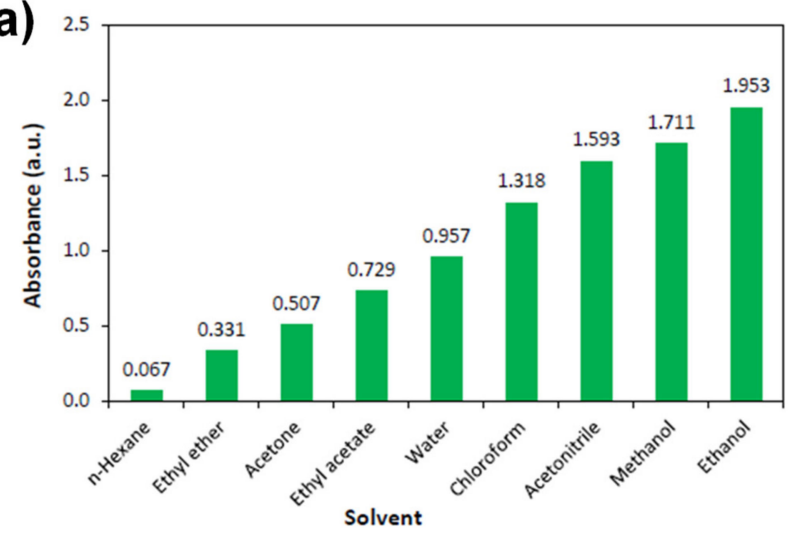

(b)

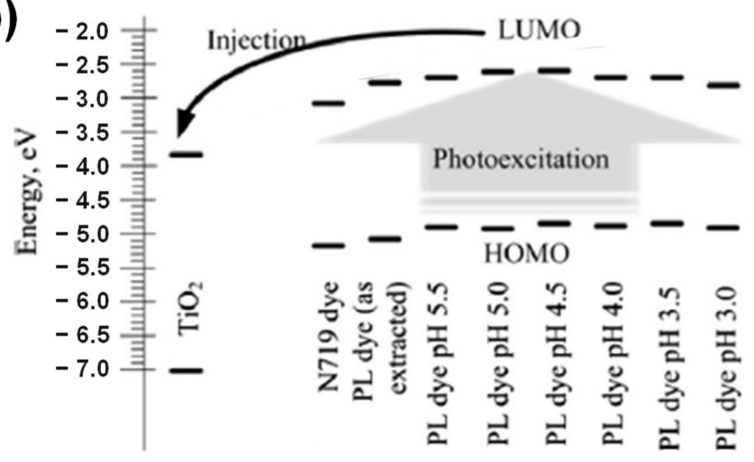

Figure 2. (a) Absorbance of the anthocyanin extracted from Areca catechu depending on the types of extracting solvents. Wavelength region of adsorption is from 400 to $800 \mathrm{~nm}$. Reprinted with permission from [71]. Copyright 2020 Elsevier. (b) HOMO and LUMO levels of the chlorophyll extracted from PLs depending on the $\mathrm{pH}$ of the extracting solvent. Reprinted with permission from [58]. Copyright 2015 Elsevier.

The $\mathrm{pH}$ adjustment of extracting solvents and the addition of acid can affect the properties of dyes, such as the highest occupied molecular orbital (HOMO) and lowest unoccupied molecular orbital (LUMO) levels, absorption spectra, polarity, and stability. The addition 
of acid changes the HOMO and LUMO levels of dyes, which is closely related to the $V_{O C}$ value. Suyitno et al. investigated the HOMO and LUMO levels of chlorophyll extracted from papaya leaves (PLs) depending on the $\mathrm{pH}$ of the extracting solvent (Figure 2b) [58]. After the $\mathrm{pH}$ changed to 3.5 by acidification, the bandgap lowered from 2.30 to $2.16 \mathrm{eV}$, and the PCE was improved four times from $0.07 \%$ to $0.28 \%$. Acidification also increases the polarity of the extracting solvents, such as ethanol or methanol, which could enhance the dye separation from source materials, thereby increasing the concentration of the dye extract solution and absorption value, which assists in higher harvesting from sunlight $[43,57,85]$. However, high-pH conditions can decompose natural dyes, thereby degrading the PCE of DSSCs. Therefore, it is important to carefully optimize the acid or alkali treatment conditions depending on the types of natural dyes.

The mixture of multiple natural dyes can absorb a wider range of wavelength of light (Figure 3a). For a high photocurrent, the LUMO and HOMO levels should also be above the conduction and valence bands of the photoanode materials, respectively, thereby increasing the injection of photoelectrons and reducing recombination loss $[79,86]$. A mixture of multiple dyes can facilitate the photoelectron injection and increase the electron lifetime due to the intermediate energy level of electrons in adjacent dye molecules (Figure 3b) $[59,87]$. Consequently, it has been reported that the PCE of DSSCs can be improved by employing a dye cocktail (Table 3). The most frequently used natural dye is anthocyanin because its carbonyl and hydroxyl groups form a stable bonding to the photoanode surface. The combination of dyes, the optimal mixing ratios of the dyes, and the resulting photovoltaic performances of the DSSCs are presented in Table 3. The optimal ratio may differ depending on the types of natural dyes and electrolytes. Kumar et al. fabricated a co-sensitized solar cell with a high PCE of $1.139 \%$ (Figure 3c) by mixing chlorophyll and anthocyanin in a ratio of 1:1 [59]. In their study, the dyes were extracted from cactus and bermudagrass, respectively. The dye-mixing ratio is important to obtain a maximum PCE. For example, Bashar et al. reported that when betalain and chlorophyll were mixed in an optimized mixing ratio of $4: 1$, a maximum PCE of $0.99 \%$ was obtained. By combining anthocyanin and chlorophyll, a maximum PCE of $1.29 \%$ was obtained in the ratio of 1:1 [29]. Instead of employing a simple mixture of multiple dyes, Kumara et al. performed the sequential adsorption of natural dyes for the layered co-sensitization (Figure 3d) [42]. The PCE of DSSCs prepared by the layered co-sensitization was $1.55 \%$, which exceeded that of DSSCs with homogenous adsorption of the dyes (1.13\%).

Table 3. Combination and ratio of natural dyes and the photovoltaic parameters.

\begin{tabular}{ccccccc}
\hline Combination of Natural Dye & Ratio & $V_{\text {OC }}(\mathbf{V})$ & $J_{S C}\left(\mathbf{m A} / \mathbf{c m}^{\mathbf{2}}\right)$ & FF & PCE (\%) & Ref. \\
\hline Anthocyanin + Chlorophyll & $1: 1$ & 0.532 & 1.45 & 0.67 & 0.5175 & {$[49]$} \\
Anthocyanin + Chlorophyll & $2: 1$ & 0.675 & 2.55 & 0.67 & 1.15 & {$[29]$} \\
Anthocyanin + Chlorophyll & $1: 1$ & 0.66 & 3.16 & 0.62 & 1.29 & 0.72 \\
Anthocyanin + Chlorophyll & $1: 1$ & 0.47 & 2.63 & 0.58 & {$[61]$} \\
Anthocyanin + Betalain & $1: 1$ & 0.56 & 1.12 & 0.6 & 0.3824 & {$[64]$} \\
Anthocyanin + Anthocyanin & $1: 1$ & 0.38 & 6.26 & 0.47 & 1.13 & {$[42]$} \\
Betalain + Chlorophyll & $1: 1$ & 0.495 & 4.97 & 0.46 & 1.139 & {$[59]$} \\
Betalain + Chlorophyll & $4: 1$ & 0.386 & 4.74 & 0.54 & 0.99 & {$[51]$} \\
Anthocyanin + Betalain + Chlorophyll & $1: 1: 1$ & 0.53 & 1.65 & 0.68 & 0.602 & {$[79]$} \\
\hline
\end{tabular}


(a)

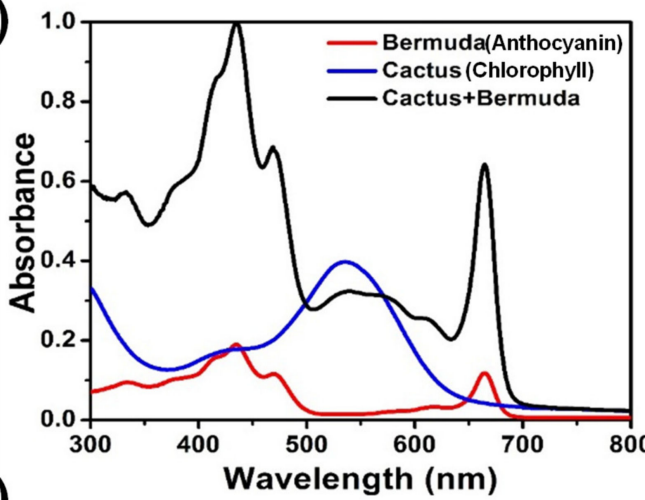

(c)

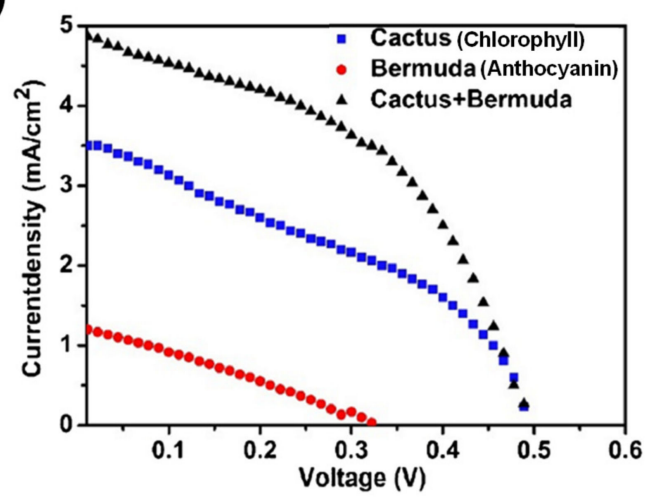

(b)

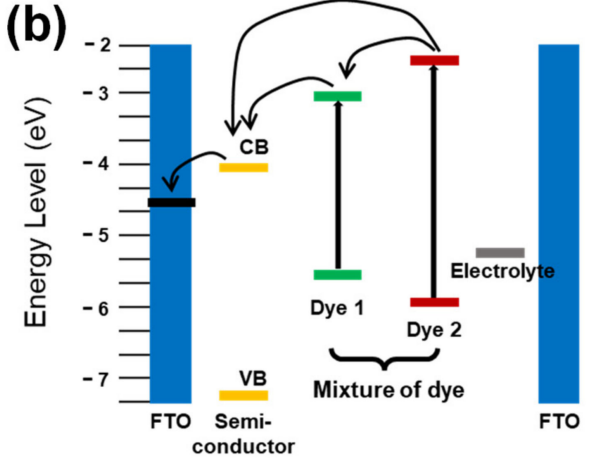

(d)
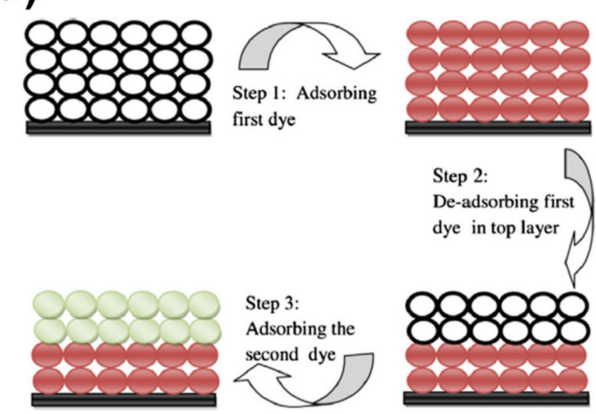

Figure 3. (a) UV-vis absorption spectra of the natural dyes from bermudagrass (anthocyanin) and cactus (chlorophyll), and their mixture. Reprinted with permission from [59]. Copyright 2016 Elsevier. (b) Energy band schematic of a DSSC containing mixed natural dyes. (c) $J$ - $V$ curve of DSSCs sensitized by chlorophyll, anthocyanin, and their mixture. Reprinted with permission from [59]. Copyright 2016 Elsevier. (d) Fabrication process of a layered co-sensitized solar cell. Reprinted with permission from [42]. Copyright 2013 Elsevier.

\section{Aqueous Electrolyte}

\subsection{Aqueous Electrolyte}

To develop eco-friendly DSSCs, efforts to replace organic electrolytes with aqueous electrolytes have progressed for several years (Table 4). In 2010, Law et al. replaced MPN with water when preparing an electrolyte (comprising 2.0 M 1-propyl-3-methylimidazolium iodide (PMII), 0.05 M iodine, 0.1 M guanidinium thiocyanate (GuSCN), and $0.5 \mathrm{M} 4$ tert-butylpyridine (TBP)). When the MPN was completely displaced by water, the PCE decreased from $5.5 \%$ to $2.4 \%$ (Figure 4 a) [88]. Similarly, Vaghasiya et al. fabricated DSSCs based on aqueous electrolytes containing organic ionic liquid. The effect of water content on the PCE was investigated, showing that the PCE reduced from $5.61 \%$ ( $0 \%$ water) to $3.46 \%(100 \%$ of water) [89].

Although ionic liquids, such as PMII, 1-butyl-3-methylimidazolium iodide (BMII), and 1-ethyl-3-methylimidazolium iodide (EMII), are typically used in organic electrolytes of DSSCs, they are not completely soluble in water, and surfactants are needed to avoid phase separation in the electrolyte. Instead of using ionic liquids, water-soluble salts, such as KI, NaI, and LiI, are employed in water-based electrolytes. Bella et al. investigated the effect of the iodide/triiodide concentration in the electrolyte and the types of counter-ions, resulting in the KI salt-based electrolyte exceeding the NaI-based one in performance, attaining a PCE value of $0.8 \%$ (D131 dye, $V_{O C}=0.488 \mathrm{~V}, J_{S C}=2.70 \mathrm{~mA} / \mathrm{cm}^{2}$, and FF $\left.=0.62\right)$ [90]. The desorption of the dye molecules from the photoanode surface in aqueous electrolytes can also decrease the performance of the DSSCs based on aqueous electrolytes than common DSSCs based on organic electrolytes. Co-absorbents, such as chenodeoxycholic acid (CDCA), which co-grafts with the dye onto the photoanode surface, prevent detachment 
and aggregation of the dye in water and reduce the charge recombination, resulting in improvement in PCE and stability of DSSCs based on an aqueous electrolyte [91-95]. With a CDCA-to-dye molar ratio of 18:1, a PCE value of $1.25 \%$ (D131 dye, $V_{O C}=0.59 \mathrm{~V}$, $J_{S C}=3.86 \mathrm{~mA} / \mathrm{cm}^{2}$, and $\left.\mathrm{FF}=0.55\right)$ was reached using an aqueous electrolyte containing $0.5 \mathrm{M} \mathrm{NaI}$ and $10 \mathrm{mM} \mathrm{I}_{2}$ [92].

To minimize the dye desorption in the presence of water and prevent evaporation or leakage of electrolytes, quasi-solid gel electrolytes were introduced by gelation of aqueous electrolytes. Gel electrolytes for DSSCs have been researched for decades for better device stability; however, several components in the electrolytes are still petroleum-derived, harmful, corrosive, or expensive [96]. For more eco-friendly DSSCs, aqueous and bioderived gels based on xanthan gum (XG) [95,97,98], cellulose [96], and agarose [99] have been developed recently. XG is a water-soluble polysaccharide and a well-known stabilizing agent widely used in the food and cosmetic industries. Additionally, because XG is thixotropic, meaning that its viscosity decreases when an external force is applied, the gel electrolyte based on XG can penetrate the mesoporous $\mathrm{TiO}_{2}$ electrode $[100,101]$. Park et al. developed half aqueous XG-based gel electrolyte with PMII and MPN solvent for DSSCs. The resulting device reached a PCE value of $4.40 \%$ even after $288 \mathrm{~h}$, indicating that the XG-based electrolyte enhanced the long-term stability [101]. Galliano et al. prepared $100 \%$ aqueous XG-based electrolyte containing NaI salt, based on which the resulting DSSC device showed only a slightly lower PCE value of $1.93 \%$ than that based on a liquid-state electrolyte $(2.28 \%)$ due to lower diffusion coefficient and UV-vis absorption. Moreover, it exhibited impressive stability after more than $1500 \mathrm{~h}$ of the aging test (Figure 4b) [97]. Further study to enhance the PCE was conducted using a cobalt-based redox couple, leading to an overall PCE of $4.47 \%$ and stability for five days [98]. The aqueous gel electrolyte based on carboxymethylcellulose (CMC) was prepared and used for DSSCs, which showed a PCE value of $0.72 \%$ in optimum CMC concentration (5.5 wt.\%), without any additives and surface treatment of the photoanode, such as $\mathrm{UVO}$ or $\mathrm{TiCl}_{4}$ [96]. In the study conducted by Haro et al., a bioderived gel electrolyte was developed using lignin, a lignocellulose material, which is the most available material on earth for biofuels. The resulting DSSCs with the lignin-based electrolyte exhibited a PCE value of $1.54 \%$ with $V_{O C}=0.63 \mathrm{~V}, J_{S C}=3.62 \mathrm{~mA} / \mathrm{cm}^{2}$, and FF $=0.67[102]$.
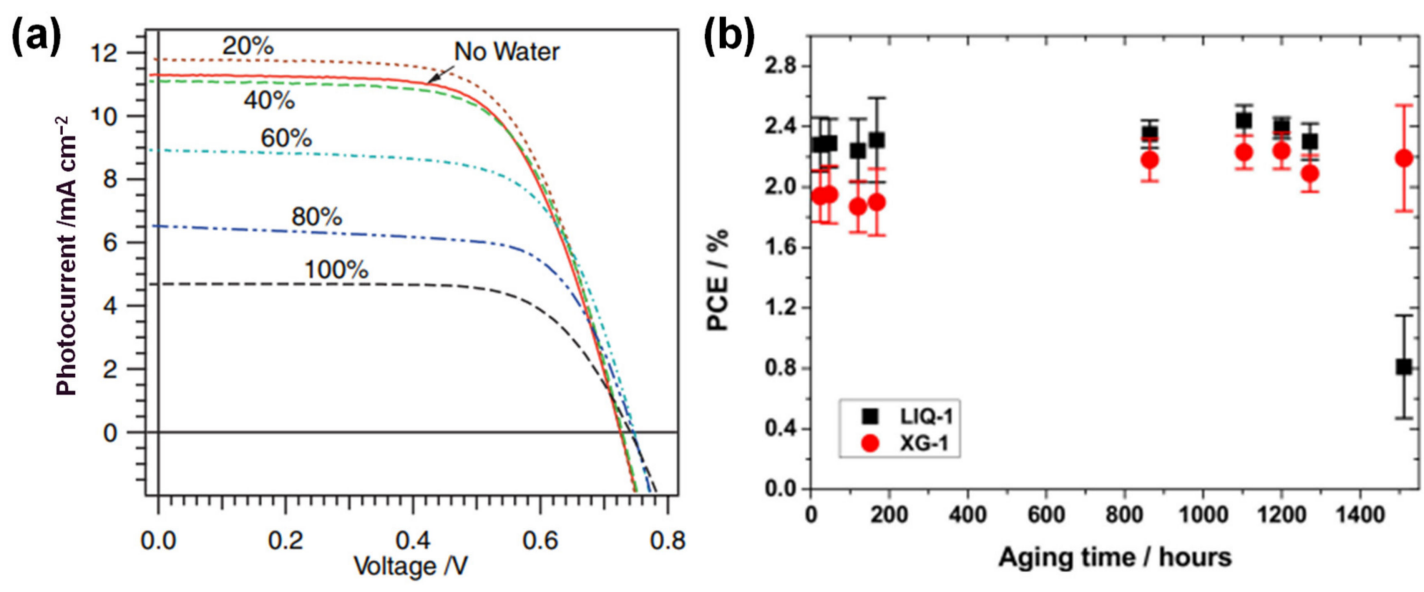

Figure 4. (a) $J$ - $V$ curves of the aqueous electrolyte-based DSSCs according to the content of water in the electrolyte based on the water-MPN mixture. Reprinted with permission from [88]. Copyright 2010 Wiley. (b) Stability in photovoltaic performance of DSSCs based on aqueous electrolytes (black squares) and hydrogel electrolytes (red circles). Reprinted with permission from [97]. Copyright 2020 MDPI. 
Table 4. Photovoltaic performance of DSSCs with aqueous electrolytes.

\begin{tabular}{|c|c|c|c|c|c|c|}
\hline Dye & Electrolyte & Content of Water $(\%)$ & Photoanode & Cathode & PCE (\%) & Ref. \\
\hline LEG4 & $\begin{array}{l}0.15 \mathrm{M} \text { TEMPO, } 0.05 \mathrm{M} \mathrm{TEMPOBF}_{4} \\
\mathrm{LiClO}_{4}, 0.2 \mathrm{M} \text { NMBI in } \mathrm{H}_{2} \mathrm{O}\end{array}$ & 100 & $\mathrm{TiO}_{2}$ & $\mathrm{Pt}$ & 4.14 & [103] \\
\hline D131 & $5.5 \mathrm{M} \mathrm{KI}, 0.05 \mathrm{M} \mathrm{I}_{2}$ in $\mathrm{H}_{2} \mathrm{O}$ & 100 & $\mathrm{TiO}_{2}$ & $\mathrm{Pt}$ & 0.73 & [90] \\
\hline $\mathrm{BH} 2$ & $\begin{array}{l}2 \mathrm{M} \mathrm{NaI}, 0.02 \mathrm{M} \mathrm{I}_{2}, 0.5 \mathrm{M} \text { GuSCN in an } \\
\text { aqueous solution saturated CDCA }\end{array}$ & 100 & $\mathrm{TiO}_{2}$ & $\mathrm{NiO}$ & 0.056 & [91] \\
\hline CdS QD & $\begin{array}{l}0.5 \mathrm{M} \mathrm{Na}_{2} \mathrm{~S}, 2 \mathrm{M} \mathrm{S}, 0.2 \mathrm{M} \mathrm{KCl} \text { in } \\
\mathrm{MeOH}: \mathrm{H}_{2} \mathrm{O}\end{array}$ & 30 & $\mathrm{TiO}_{2}$ & $\mathrm{Pt}$ & 1.15 & [104] \\
\hline \multirow{2}{*}{ N719/Z907 } & $\begin{array}{l}2 \mathrm{M} \mathrm{NaI}, 0.02 \mathrm{M} \mathrm{I}_{2}, 0.5 \mathrm{M} \mathrm{GuSCN} \\
\text { in } \mathrm{H}_{2} \mathrm{O}\end{array}$ & \multirow{2}{*}{100} & \multirow{2}{*}{$\mathrm{TiO}_{2}$} & \multirow{2}{*}{$\mathrm{Pt}$} & 0.68 & \multirow{2}{*}{ [105] } \\
\hline & $\begin{array}{l}2 \mathrm{M} \mathrm{NaI}, 0.02 \mathrm{M} \mathrm{I}_{2}, 0.5 \mathrm{M} \mathrm{GuSCN} \text {, and } \\
1 \mathrm{~g} \text { natural rubber in } \mathrm{H} 2 \mathrm{O}\end{array}$ & & & & 0.46 & \\
\hline JK-259 & \multirow{2}{*}{$\begin{array}{l}2 \mathrm{M} \text { PMMI, } 0.05 \mathrm{M} \mathrm{I}_{2}, 0.1 \mathrm{~m} \text { GuSCN, } \\
0.5 \mathrm{M} \text { TBP, } 1 \% \text { Triton } \mathrm{X}-100 \text { in } \mathrm{H}_{2} \mathrm{O}\end{array}$} & \multirow{2}{*}{100} & \multirow{2}{*}{$\mathrm{TiO}_{2}$} & \multirow{2}{*}{$\mathrm{Pt}$} & 1.16 & \multirow{2}{*}{ [106] } \\
\hline JK-262 & & & & & 2.1 & \\
\hline \multirow{2}{*}{ N719 } & $\begin{array}{l}2 \mathrm{M} \mathrm{NaI}, 0.2 \mathrm{M} \mathrm{I}_{2}, 0.1 \mathrm{M} \mathrm{GuSCN} \\
\text { in } \mathrm{H}_{2} \mathrm{O}\end{array}$ & \multirow{2}{*}{100} & \multirow{2}{*}{$\mathrm{TiO}_{2}$} & \multirow{2}{*}{$\mathrm{Pt}$} & 2.51 & \multirow[t]{2}{*}{ [107] } \\
\hline & $\begin{array}{l}2 \mathrm{M} \mathrm{NaI}, 0.2 \mathrm{M} \mathrm{I}_{2}, 0.1 \mathrm{M} \mathrm{GuSCN} \text {, and } \\
0.2 \text { wt. } \% \text { FC- } 134 \text { in } \mathrm{H}_{2} \mathrm{O}\end{array}$ & & & & 3.69 & \\
\hline T169 & $\mathrm{T}$-/DS in the presence of $\mathrm{H}_{2} \mathrm{O}_{2}$ & 100 & $\mathrm{TiO}_{2}$ & PEDOT & 4.5 & [108] \\
\hline D205 & 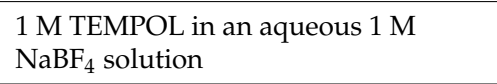 & 100 & $\mathrm{TiO}_{2}$ & Nafion & 2.1 & [109] \\
\hline D131 & $\begin{array}{l}0.5 \mathrm{M} \text { TEMPOL in an aqueous } 0.5 \mathrm{M} \\
\mathrm{NaCl} \text { solution in the presence of } \\
0.1 \mathrm{M} \mathrm{H}_{2} \mathrm{O}_{2}\end{array}$ & 100 & $\mathrm{TiO}_{2}$ & $\mathrm{Pt}$ & 1.3 & [110] \\
\hline \multirow{3}{*}{ TG6 } & \multirow{3}{*}{$\begin{array}{l}2 \mathrm{M} \text { PMMI, } 0.05 \mathrm{M} \mathrm{I}_{2}, 0.1 \mathrm{M} \text { GuSCN, } \\
0.5 \mathrm{M} \text { TBP in MPN: } \mathrm{H}_{2} \mathrm{O}\end{array}$} & 0 & \multirow{3}{*}{$\mathrm{TiO}_{2}$} & \multirow{3}{*}{$\mathrm{Pt}$} & 5.5 & \multirow{3}{*}[88]{} \\
\hline & & 60 & & & 4.5 & \\
\hline & & 100 & & & 2.4 & \\
\hline D131 & \multirow{3}{*}{$0.5 \mathrm{M} \mathrm{NaI}, 25 \mathrm{mM} \mathrm{I}_{2}$ in $\mathrm{H}_{2} \mathrm{O}$} & \multirow{3}{*}{100} & \multirow{3}{*}{$\mathrm{TiO}_{2}$} & \multirow{3}{*}{$\mathrm{Pt}$} & 0.2 & \multirow{3}{*}{ [94] } \\
\hline D205 & & & & & 0.1 & \\
\hline D149 & & & & & 0.14 & \\
\hline V35 & $\begin{array}{l}2 \mathrm{M} \mathrm{KI}, 0.01 \mathrm{M} \mathrm{I}_{2} \text { in an aqueous } \\
\text { solution saturated CDCA }\end{array}$ & 100 & $\mathrm{TiO}_{2}$ & PEDOT & 3.01 & [111] \\
\hline SK3 & $2 \mathrm{M} \mathrm{LiI}, 0.02 \mathrm{M} \mathrm{I}_{2}, 1 \mathrm{M} \mathrm{GuSCN}$ in $\mathrm{H}_{2} \mathrm{O}$ & 100 & $\mathrm{TiO}_{2}$ & $\mathrm{Pt}$ & 1.27 & [112] \\
\hline \multirow{2}{*}{ N719 } & $1 \mathrm{M}$ LiI, $0.02 \mathrm{M} \mathrm{I}_{2}$ in $\mathrm{H}_{2} \mathrm{O}$ & \multirow{2}{*}{100} & \multirow{2}{*}{$\mathrm{TiO}_{2}$} & $D_{0}$ & 0.1 & [113] \\
\hline & $1 \mathrm{M} \mathrm{LiI}, 0.02 \mathrm{M} \mathrm{I}_{2}$, Rice starch in $\mathrm{H}_{2} \mathrm{O}$ & & & Pt & 0.35 & \\
\hline$D 121$ & $\begin{array}{l}5 \mathrm{M} \mathrm{NaI}, 0.03 \mathrm{M} \mathrm{I}_{2} \text { in an aqueous } \\
\text { solution saturated CDCA }\end{array}$ & 100 & $\mathrm{TiO}$ & Dt & 2.44 & [971 \\
\hline D131 & $\begin{array}{l}5 \mathrm{M} \mathrm{NaI}, 0.03 \mathrm{M} \mathrm{I}_{2}, 5 \mathrm{wt} . \% \text { of } \mathrm{XG} \text { in an } \\
\text { aqueous solution saturated CDCA }\end{array}$ & 100 & $11 \mathrm{U}_{2}$ & $\mathrm{Pt}$ & 2.23 & [9/] \\
\hline MK2 & $\begin{array}{l}0.21 \mathrm{M} \mathrm{Co}(\mathrm{bpy})_{3} \mathrm{Cl}_{2}, 0.07 \mathrm{M} \\
\mathrm{Co}(\mathrm{bpy})_{3} \mathrm{Cl}_{3}, 1.5 \text { wt. } \% \text { of } \mathrm{XG} \text { in } \mathrm{H}_{2} \mathrm{O}\end{array}$ & 100 & $\mathrm{TiO}_{2}$ & $\mathrm{Pt}$ & 4.47 & [98] \\
\hline D121 & $\begin{array}{l}5.5 \mathrm{M} \mathrm{KI} 0.05 \mathrm{M} \mathrm{I}_{2}, 5.5 \text { wt.\% CMC } \\
\text { in } \mathrm{H}_{2} \mathrm{O}\end{array}$ & 100 & TiO & & 0.72 & {$[061$} \\
\hline D131 & $\begin{array}{l}\text { 4.5 M NaI, } 0.05 \mathrm{M} \mathrm{I}_{2}, 5.5 \text { wt.\% CMC } \\
\text { in } \mathrm{H}_{2} \mathrm{O}\end{array}$ & 100 & $\mathrm{TiO}_{2}$ & $\mathrm{Pt}$ & 0.61 & [96] \\
\hline N3 & - & 190 & & & 0.6 & \\
\hline N719 & $0.5 \mathrm{M} \mathrm{Kl}, 0.025 \mathrm{M}_{2}$ in $\mathrm{H}_{2} \mathrm{O}$ & 100 & $\pi \cdot 0$ & $D$ & 0.5 & [11 \\
\hline N3 & $0.5 \mathrm{M} \mathrm{KI}, 0.025 \mathrm{M} \mathrm{I}_{2}$ in $35 \%$ aqueous & 65 & $110_{2}$ & $\mathrm{Pt}$ & 1.3 & {$[114,115]$} \\
\hline N719 & ethanol solution & 65 & & & 1.1 & \\
\hline D131 & $\begin{array}{l}5 \mathrm{M} \mathrm{NaI}, 0.01 \mathrm{M} \mathrm{I}_{2} \text { in an aqueous } \\
\text { solution saturated CDCA }\end{array}$ & 100 & $\mathrm{TiO}_{2}$ & $\mathrm{Pt}$ & 2.37 & [116] \\
\hline N3 & $0.5 \mathrm{M}$ LiI, $0.025 \mathrm{M} \mathrm{I}_{2}$ in $\mathrm{H}_{2} \mathrm{O}$ & 100 & $\mathrm{SnO}_{2} / \mathrm{TiO}_{2}$ & $\mathrm{Pt}$ & 0.66 & [117] \\
\hline
\end{tabular}




\subsection{Efforts to Improve Performance}

The relatively poor performance of DSSCs using aqueous electrolytes compared to organic electrolytes can be attributed to various causes: (1) less wettability of the photoanode surface $[104,107,108,112]$; (2) desorption of the dye from the surface of the semiconductor [89,118-120]; (3) reduction in the diffusion coefficient [89,104,107,108,112]; (4) recombination derived from a higher concentration of free iodine [91,121]; and (5) negative shift of the conduction band [122-124]. To overcome these problems, endeavors to improve performances, such as adding surfactants, developing novel redox couples and hydrophobic sensitizers, and chemical and morphological modification of the photoanode surface have been performed. In this chapter, we will discuss the efforts to improve aqueous DSSCs.

\subsubsection{Development of Novel Redox Couples and Photosensitizers}

To overcome the low $V_{O C}$ and $J_{S C}$ values of aqueous DSSCs, novel redox couples and sensitizers were developed to have fast kinetics and a high positive redox potential, which is related to high $V_{O C}$. The radical of 4-hydroxy-2,2,6,6-tetramethlypiperidinoxyl (4hydroxy-TEMPO or TEMPOL (Figure $5 \mathrm{a}$ )), which has $0.7 \mathrm{~V}$ of redox potential in water, was developed and was added to an aqueous electrolyte in DSSCs with a D131 dye $[109,110]$, resulting in a PCE value of $1.3 \%\left(V_{O C}=0.81 \mathrm{~V}, J_{S C}=3.1 \mathrm{~mA} / \mathrm{cm}^{2}\right.$, and $\left.\mathrm{FF}=0.56\right)$ [110]. Additionally, Kato et al. immobilized TEMPOL on the Nafion layer coated on a counter electrode to enhance the reduction peak current and achieved a PCE value of $2.1 \%$ with $1.0 \mathrm{M}$ TEMPOL $/ \mathrm{TEMPOL}^{+}$and D205 dye $\left(V_{O C}=0.69 \mathrm{~V}, J_{S C}=4.5 \mathrm{~mA} / \mathrm{cm}^{2}\right.$, and FF $\left.=0.64\right)$ [109]. The high $V_{O C}$ compared to that of the previously reported aqueous systems was due to the high positive redox potential of the TEMPO/TEMPO ${ }^{+}$redox couple [103]. ISC remained constant or only slightly higher than without TEMPO $/ \mathrm{TEMPO}^{+}$, which was attributed to the recombination between $\mathrm{TEMPO}^{+}$and the use of the highly hydrophobic dyes $[108,125,126]$. Fayad et al. introduced a new water-soluble redox couple based on a thiolate/disulfide $\left(\mathrm{T}^{-} / \mathrm{DS}\right)$ in an aqueous electrolyte and new zwitterionic dye (T169) to improve poor wetting, showing excellent performance with $V_{O C}=0.55 \mathrm{~V}, J_{S C}=13.30 \mathrm{~mA} / \mathrm{cm}^{2}, \mathrm{FF}=0.62$, and $\mathrm{PCE}=4.50 \%$ [108].

(a)

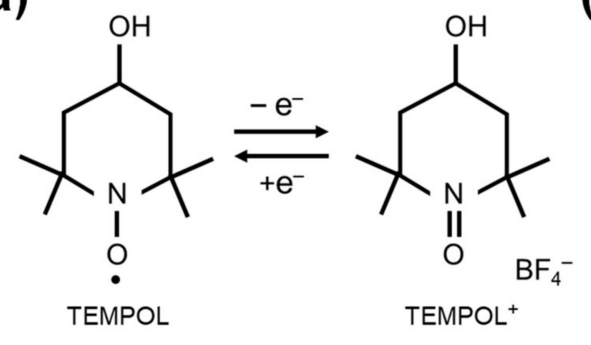

(b)

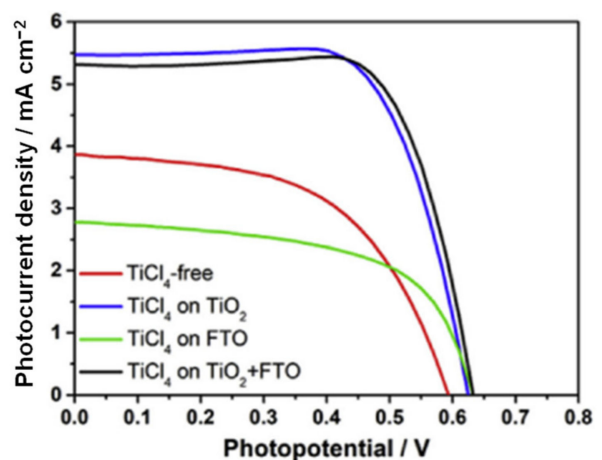

Figure 5. (a) Redox reaction of the TEMPOL/TEMPOL ${ }^{+}$. (b) $J-V$ curves of the DSSCs based on aqueous electrolytes containing $5 \mathrm{M} \mathrm{NaI}$ and $0.01 \mathrm{M} \mathrm{I}_{2}$, with or without $\mathrm{TiCl}_{4}$ treatment on photoanodes. Reprinted with permission from [116]. Copyright 2019 Elsevier.

\subsubsection{Interface Engineering of Photoanodes and Aqueous Electrolytes}

Surfactants are widely used to impede phase separations in aqueous electrolytes, including organic ionic liquids $[88,127]$, and improve incomplete wettability between hydrophobic semiconductor photoanode and aqueous electrolytes by reducing the interfacial tension $[106,128]$. For a $100 \%$ aqueous electrolyte, Zhang et al. applied ionic surfactants (AOT and FK-1 as anionic surfactants and CTAB and FC-134 as cationic surfactants) to $100 \%$ water-electrolyte incorporating $\mathrm{NaI}$ and $\mathrm{I}_{2}$. Both the anionic and cationic surfactants could improve the PCE from $2.51 \%$ (without surfactant) to $2.98 \%$ (with 0.1 wt. $\%$ of AOT) 
and $3.96 \%$ (with 0.2 wt.\% of FC-134) due to the better wettability of the aqueous electrolyte and dye-coated $\mathrm{TiO}_{2}$ layer [107]. However, since the surfactants could decrease the DSSC performance by imposing a diffusion limitation of the redox couple, caution should be taken to use the appropriate redox couple and surfactants [103].

Chemical and morphological modification of photoanode surfaces could also enhance the performance of DSSCs. Miyasaka et al. treated a $\mathrm{TiO}_{2}$ photoanode with ozone and UV light to increase its hydrophilicity and absorbed dye on the $\mathrm{TiO}_{2}$ surface in the presence of tert-butylpyridine (TBP) to reinforce the dye- $\mathrm{TiO}_{2}$ binding. The PCE was enhanced from $0.6 \%$ to $1.1 \%$ with an aqueous electrolyte $\left(0.5 \mathrm{M} \mathrm{KI}\right.$ and $25 \mathrm{mM} \mathrm{I}_{2}$ in water) $[114,115]$. Furthermore, an increase in the active surface area is a method for improving the photocurrent and, therefore, the PCE of DSSCs. $\mathrm{TiCl}_{4}$ treatment on $\mathrm{TiO}_{2}$ surface forms a rough nanolayer of $\mathrm{TiO}_{2}$, causing the surface area augmentation and increasing the light-harvesting efficiency and adsorption of dye $[129,130]$. The $\mathrm{TiCl}_{4}$ treatment on the $\mathrm{TiO}_{2}$ surface also inhibited the charge recombination between the electrons and the oxidized redox couple through the barrier effect $[116,131,132]$. In fact, in research activities on various types of solar cells, including DSSCs, $\mathrm{TiCl}_{4}$ treatment has been actively utilized to increase efficiency. Bella et al. used the $\mathrm{TiCl}_{4}$ treatment, which improved the PCE of DSSCs based on an aqueous electrolyte comprising $\mathrm{NaI}$ and $\mathrm{I}_{2}$ from $1.25 \%$ to $2.37 \%$ (Figure $5 \mathrm{~b}$ ) [116]. The $\mathrm{TiCl}_{4}$ liquid deposition process could damage the semiconductor film, resulting in flaking off from the fluorine-doped tin oxide (FTO) after a long treatment time $(>4 \mathrm{~h})$. Therefore, Pham et al. introduced a shorter $(<1 \mathrm{~h})$ and more effective nanoTiO $\mathrm{T}_{2}$-layer-coating method on $\mathrm{SnO}_{2}$ film using a $\left(\mathrm{NH}_{4}\right)_{2} \mathrm{TiF}_{6}$ solution. With this approach, the PCE increased ten times, from $0.067 \%$ (no treatment) to $0.66 \%\left(\left(\mathrm{NH}_{4}\right)_{2} \mathrm{TiF}_{6}\right.$ treatment), which was higher compared to the $0.204 \%$ improvement using the $\mathrm{TiCl}_{4}$ solution treatment [117]. S. Castro et al. employed anchoring molecules, trioctylmethyl ammonium dodecanedioate (DTMA) containing carboxyl groups and alkyl chains, to the $\mathrm{TiO}_{2}$ layer before the dye adsorption step. The molecules are anchored onto the $\mathrm{TiO}_{2}$ layer by acting as selective physical barriers that hinder the triiodide molecules from contacting the $\mathrm{TiO}_{2}$ layer [133].

\section{Efforts to Obtain Fully Eco-Friendly DSSCs}

In previous chapters, we discussed the studies where artificially synthesized dyes and organic solvent-based electrolytes were individually replaced with eco-friendly materials of natural dyes and water-based electrolytes, respectively. Here, studies to realize fully "green" DSSC s by simultaneously using both natural dyes and aqueous electrolytes are introduced (Figure 6a).

$\mathrm{Gu}$ et al. attained a PCE value of $0.01 \%$ using natural dye from purple cabbage and an aqueous electrolyte, including $0.5 \mathrm{M} \mathrm{KI}$ and $50 \mathrm{mM} \mathrm{I}_{2}$ [134]. Kim et al. improved the PCE of DSSCs based on chlorophyll and $100 \%$ aqueous electrolyte with $\mathrm{KI} / \mathrm{I}_{2}$ via $\mathrm{O}_{2}$ plasma treatment. The treatment enhanced the hydrophilicity of the $\mathrm{TiO}_{2}$ photoanode surface, thereby increasing the PCE from $0.023 \%\left(V_{O C}=0.46 \mathrm{~V}, J_{S C}=0.089 \mathrm{~mA} / \mathrm{cm}^{2}\right.$, and $\left.\mathrm{FF}=0.56\right)$ to $0.033 \%\left(V_{O C}=0.46 \mathrm{~V}, J_{S C}=0.14 \mathrm{~mA} / \mathrm{cm}^{2}\right.$, and $\left.\mathrm{FF}=0.52\right)$ [118]. Furthermore, Hon et al. used a 35\% aqueous ethanol electrolyte, including $0.1 \mathrm{M} \mathrm{Ce}\left(\mathrm{NO}_{3}\right)_{3} / 0.05 \mathrm{Ce}\left(\mathrm{NO}_{3}\right)_{4}$ and $\mathrm{Au}$ nanoparticles, which can create a Schottky barrier between the Au nanoparticles and the $\mathrm{TiO}_{2}$ electrode to enhance the photocurrent. They achieved a PCE value of $1.49 \%$ [135].

Other examples of approaches for more eco-friendly and low-cost DSSCs, besides using natural dyes and aqueous electrolytes, are to use a CoS-deposited carbon fabric [136] and graphite electrode [134] as a counter electrode or develop the eco-friendly synthesis process of $\mathrm{TiO}_{2}$ using Terminalia arjuna bark extract. As an intriguing approach for ecofriendly DSSCs, Koo et al. reported a biomimetic, regenerable DSSC with microfluidic hydrogels inspired by the vein of a leaf (Figure 6b), which showed a PCE value of $0.21 \%$, with $V_{O C}=0.63 \mathrm{~V}, J_{S C}=0.59 \mathrm{~mA} / \mathrm{cm}^{2}$, and FF $=0.57$. In microfluidic DSSCs with organic eosin $\mathrm{Y}$ dye, the dyes and aqueous electrolytes could be repeatedly infused and supplied to the device through the microfluidic hydrogel network, thereby continuously regenerating the DSSCs [99]. 
(a)

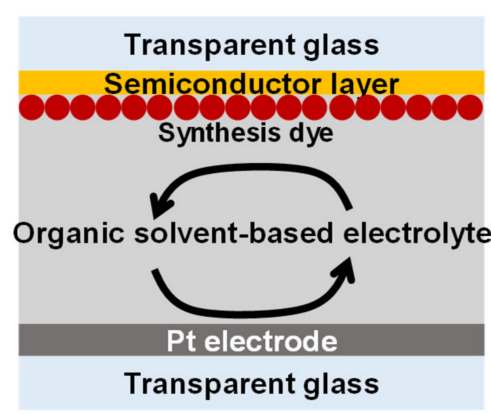

\section{Commercial DSSC}

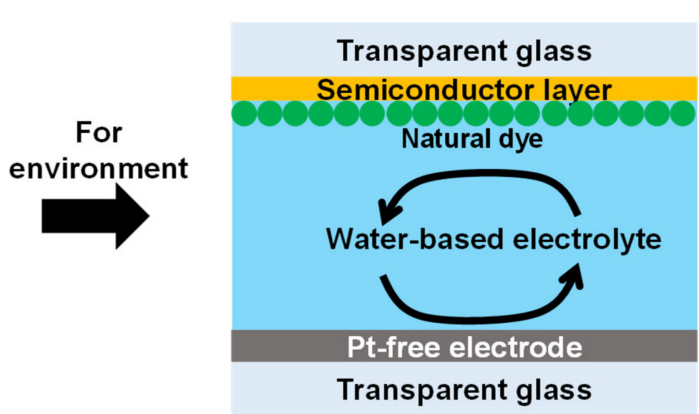

Eco-friendly DSSC

(b)

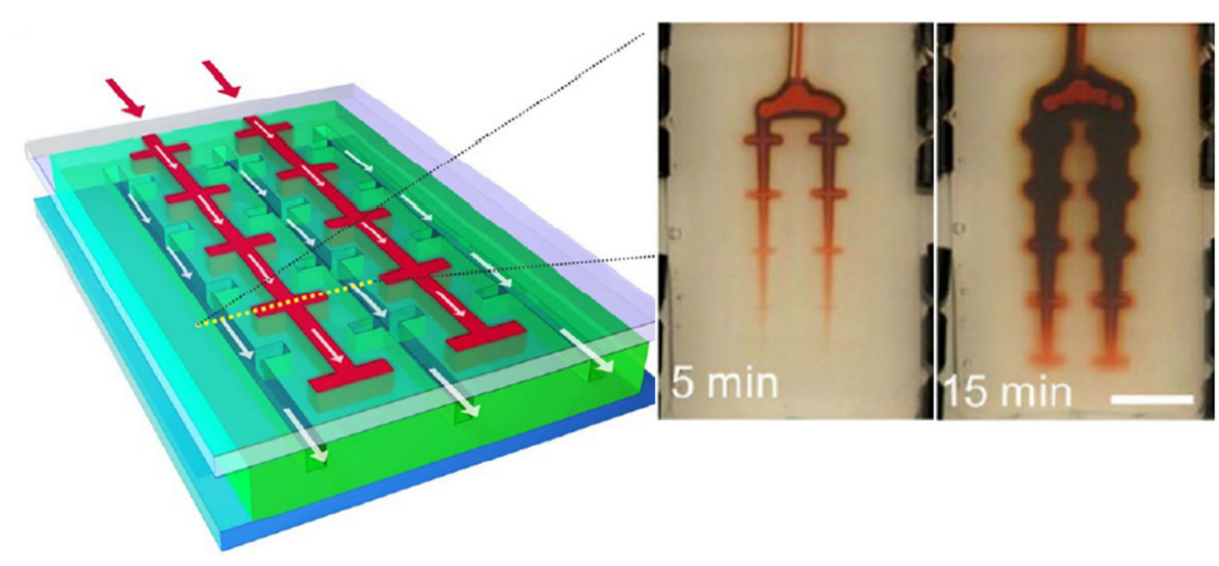

Figure 6. (a) Scheme of general DSSCs containing a synthesized dye and organic electrolyte and eco-friendly DSSCs containing a natural dye and aqueous electrolyte. (b) DSSC assembled with an aqueous gel electrolyte mimicking a leaf vein. Reprinted with permission from [99]. Copyright 2013 Elsevier.

\section{Conclusions and Future Outlooks}

Due to low cost, facile fabrication, and high conversion efficiency, DSSCs have attracted much attention as new renewable energy devices. To replace the expensive and toxic materials in typical DSSCs with less harmful ones, efforts using natural dyes and aqueous electrolytes have been made. The DSSCs based on natural dyes and aqueous electrolytes, however, showed a lower efficiency than conventional DSSCs due to poor wettability, desorption of dye, low-diffusion coefficient of ions, recombination of photoanodes, and negative shift of the conduction band. Various efforts, such as the combination of the dyes, addition of the surfactants, and treatment of the photoanode, have improved the performance of aqueous DSSCs. Today, a few studies on fully eco-friendly DSSCs have been reported, even though the efficiency is still very low. Attaining long-term stability of the eco-friendly DSSCs is another key task. Fortunately, it has been reported that an aqueous electrolyte could be more durable than an organic solvent-based electrolyte, possibly due to the low volatility, high surface tension, high specific heat, and high boiling point of water $[19,90]$. Research on fully eco-friendly DSSCs with enhanced efficiency and stability should be conducted to develop more practical energy devices with the minimum environmental footprint.

Author Contributions: Conceptualization, J.-H.K., D.-H.K. and H.-J.K.; investigation, J.-H.K., D.-H.K. and H.-J.K.; data curation, J.-H.K., D.-H.K. and H.-J.K.; writing, J.-H.K., D.-H.K., J.-H.S. and H.-J.K.; review and editing, J.-H.S. and H.-J.K.; supervision, J.-H.S. and H.-J.K. All authors have read and agreed to the published version of the manuscript.

Funding: This work was supported by the Advanced Research Project funded by SeoulTech (Seoul National University of Science and Technology). 


\section{Institutional Review Board Statement: Not applicable.}

Informed Consent Statement: Not applicable.

Data Availability Statement: Not applicable.

Conflicts of Interest: The authors declare no conflict of interest.

\section{References}

1. Ellabban, O.; Abu-Rub, H.; Blaabjerg, F. Renewable energy resources: Current status, future prospects and their enabling technology. Renew. Sustain. Energy Rev. 2014, 39, 748-764. [CrossRef]

2. Mekhilef, S.; Saidur, R.; Safari, A. A review on solar energy use in industries. Renew. Sustain. Energy Rev. 2011, 15, 1777-1790. [CrossRef]

3. Wang, H.; Feng, Y.; Yu, H.; Dong, L.; Zhai, F.; Tang, J.; Ge, J.; Feng, W. Utilisation of photo-thermal energy and bond enthalpy based on optically triggered formation and dissociation of coordination bonds. Nano Energy 2021, 89, 106401. [CrossRef]

4. Green, M.A. Photovoltaic principles. Physica E 2002, 14, 11-17. [CrossRef]

5. Bouich, A.; Ullah, S.; Ullah, H.; Mollar, M.; Marí, B.; Touhami, M.E. Electrodeposited CdZnS/CdS/CIGS/Mo: Characterization and solar cell performance. JOM 2020, 72, 615-620. [CrossRef]

6. Bouich, A.; Ullah, S.; Marí, B.; Atourki, L.; Touhami, M.E. One-step synthesis of $\mathrm{FA}_{1-\mathrm{x}} \mathrm{GA}_{\mathrm{x}} \mathrm{PbI}_{3}$ perovskites thin film with enhanced stability of alpha $(\alpha)$ phase. Mater. Chem. Phys. 2021, 258, 123973. [CrossRef]

7. Wu, Q.; Guo, J.; Sun, R.; Guo, J.; Jia, S.; Li, Y.; Wang, J.; Min, J. Slot-die printed non-fullerene organic solar cells with the highest efficiency of $12.9 \%$ for low-cost PV-driven water splitting. Nano Energy 2019, 61, 559-566. [CrossRef]

8. Rho, W.-Y.; Jeon, H.; Kim, H.-S.; Chung, W.-J.; Suh, J.S.; Jun, B.-H. Recent progress in dye-sensitized solar cells for improving efficiency: $\mathrm{TiO}_{2}$ nanotube arrays in active layer. J. Nanomater. 2015, 2015, 247689. [CrossRef]

9. Mehmood, U.; Rahman, S.-u.; Harrabi, K.; Hussein, I.A.; Reddy, B. Recent advances in dye sensitized solar cells. Adv. Mater. Sci. 2014, 2014, 974782. [CrossRef]

10. O'Regan, B.; Grätzel, M. A Low-Cost, High-Efficiency Solar Cell Based on Dye-Sensitized Colloidal TiO 2 Films. Nature 1991, 353, 737-740. [CrossRef]

11. Kakiage, K.; Aoyama, Y.; Yano, T.; Oya, K.; Fujisawa, J.-i.; Hanaya, M. Highly-efficient dye-sensitized solar cells with collaborative sensitization by silyl-anchor and carboxy-anchor dyes. Chem. Commun. 2015, 51, 15894-15897. [CrossRef]

12. Eom, Y.K.; Kang, S.H.; Choi, I.T.; Yoo, Y.; Kim, J.; Kim, H.K. Significant light absorption enhancement by a single heterocyclic unit change in the $\pi$-bridge moiety from thieno [3,2-b] benzothiophene to thieno $[3,2-b]$ indole for high performance dye-sensitized and tandem solar cells. J. Mater. Chem. A 2017, 5, 2297-2308. [CrossRef]

13. Jitchati, R.; Thathong, Y.; Wongkhan, K. Three synthetic routes to a commercial N3 dye. Int. J. Appl. Phys. Math. 2012, 2, 1076. [CrossRef]

14. Rajan, A.K.; Cindrella, L. Studies on new natural dye sensitizers from Indigofera tinctoria in dye-sensitized solar cells. Opt. Mater. 2019, 88, 39-47. [CrossRef]

15. Hemmatzadeh, R.; Mohammadi, A. Improving optical absorptivity of natural dyes for fabrication of efficient dye-sensitized solar cells. J. Theor. Appl. Phys. 2013, 7, 57. [CrossRef]

16. Gong, J.; Liang, J.; Sumathy, K. Review on dye-sensitized solar cells (DSSCs): Fundamental concepts and novel materials. Renew. Sustain. Energy Rev. 2012, 16, 5848-5860. [CrossRef]

17. Buitrago, E.; Novello, A.M.; Meyer, T. Third-Generation Solar Cells: Toxicity and Risk of Exposure. Helv. Chim. Acta 2020, 103, e2000074. [CrossRef]

18. Carella, A.; Borbone, F.; Centore, R. Research progress on photosensitizers for DSSC. Front. Chem. 2018, 6, 481. [CrossRef]

19. Bella, F.; Gerbaldi, C.; Barolo, C.; Grätzel, M. Aqueous dye-sensitized solar cells. Chem. Soc. Rev. 2015, 44, 3431-3473. [CrossRef]

20. Iftikhar, H.; Sonai, G.G.; Hashmi, S.G.; Nogueira, A.F.; Lund, P.D. Progress on electrolytes development in dye-sensitized solar cells. Materials 2019, 12, 1998. [CrossRef]

21. Turchen, S.G.; Manoguerra, A.S.; Whitney, C. Severe cyanide poisoning from the ingestion of an acetonitrile-containing cosmetic Am. J. Emerg. Med. 1991, 9, 264-267. [CrossRef]

22. Mueller, M.; Borland, C. Delayed cyanide poisoning following acetonitrile ingestion. Postgrad. Med. J. 1997, 73, 299-300. [CrossRef]

23. Brent, J.; McMartin, K.; Phillips, S.; Burkhart, K.K.; Donovan, J.W.; Wells, M.; Kulig, K. Fomepizole for the treatment of ethylene glycol poisoning. N. Engl. J. Med. 1999, 340, 832-838. [CrossRef]

24. Bove, K.E. Ethylene glycol toxicity. Am. J. Clin. Pathol. 1966, 45, 46-50. [CrossRef]

25. Schep, L.J.; Knudsen, K.; Slaughter, R.J.; Vale, J.A.; Mégarbane, B. The clinical toxicology of gamma-hydroxybutyrate, gammabutyrolactone and 1,4-butanediol. Clin. Toxicol. 2012, 50, 458-470. [CrossRef]

26. Wood, D.M.; Brailsford, A.D.; Dargan, P.I. Acute toxicity and withdrawal syndromes related to gamma-hydroxybutyrate (GHB) and its analogues gamma-butyrolactone (GBL) and 1,4-butanediol (1,4-BD). Drug Test. Anal. 2011, 3, 417-425. [CrossRef] 
27. Nazeeruddin, M.K.; De Angelis, F.; Fantacci, S.; Selloni, A.; Viscardi, G.; Liska, P.; Ito, S.; Takeru, B.; Grätzel, M. Combined experimental and DFT-TDDFT computational study of photoelectrochemical cell ruthenium sensitizers. J. Am. Chem. Soc. 2005, 127, 16835-16847. [CrossRef]

28. Wen, P.; Han, Y.; Zhao, W. Influence of $\mathrm{TiO}_{2}$ nanocrystals fabricating dye-sensitized solar cell on the absorption spectra of N719 sensitizer. Int. J. Photoenergy 2012, 2012, 906198. [CrossRef]

29. Chang, H.; Kao, M.-J.; Chen, T.-L.; Chen, C.-H.; Cho, K.-C.; Lai, X.-R. Characterization of natural dye extracted from wormwood and purple cabbage for dye-sensitized solar cells. Int. J. Photoenergy 2013, 2013, 159502. [CrossRef]

30. Vougioukalakis, G.C.; Philippopoulos, A.I.; Stergiopoulos, T.; Falaras, P. Contributions to the development of ruthenium-based sensitizers for dye-sensitized solar cells. Coord. Chem. Rev. 2011, 255, 2602-2621. [CrossRef]

31. Sharma, G.; Singh, S.P.; Kurchania, R.; Ball, R. Cosensitization of dye sensitized solar cells with a thiocyanate free Ru dye and a metal free dye containing thienylfluorene conjugation. RSC Adv. 2013, 3, 6036-6043. [CrossRef]

32. Sharma, K.; Sharma, V.; Sharma, S. Dye-sensitized solar cells: Fundamentals and current status. Nanoscale Res. Lett. 2018, 13, 381 [CrossRef] [PubMed]

33. Nam, S.-H.; Lee, K.H.; Yu, J.-H.; Boo, J.-H. Review of the development of dyes for dye-sensitized solar cells. Appl. Sci. Converg. Technol. 2019, 28, 194-206. [CrossRef]

34. De Freitas, E.S.; Da Silva, P.B.; Chorilli, M.; Batista, A.A.; de Oliveira Lopes, É.; Silva, M.M.d.; Leite, C.Q.F.; Pavan, F.R Nanostructured lipid systems as a strategy to improve the in vitro cytotoxicity of ruthenium (II) compounds. Molecules 2014, 19, 5999-6008. [CrossRef]

35. Dragutan, I.; Dragutan, V.; Demonceau, A. Special Issue on Ruthenium Complexes. Molecules 2017, 2, 255. [CrossRef]

36. Tojo, G.; Fernández, M. Ruthenium tetroxide and other ruthenium compounds. In Oxidation of Primary Alcohols to Carboxylic Acids, 1st ed.; Springer: New York, NY, USA, 2007; pp. 61-78.

37. Elnagar, M.M.; Samir, S.; Shaker, Y.M.; Abdel-Shafi, A.A.; Sharmoukh, W.; Abdel-Aziz, M.S.; Abou-El-Sherbini, K.S. Synthesis, characterization, and evaluation of biological activities of new $4^{\prime}$-substituted ruthenium (II) terpyridine complexes: Prospective anti-inflammatory properties. Appl. Organomet. Chem. 2021, 35, e6024. [CrossRef]

38. Ismail, M.; Akhtar, K.; Khan, M.; Kamal, T.; Khan, M.A.; Asiri, A.M.; Seo, J.; Khan, S.B. Pollution, toxicity and carcinogenicity of organic dyes and their catalytic bio-remediation. Curr. Pharm. Des. 2019, 25, 3645-3663. [CrossRef]

39. Mariotti, N.; Bonomo, M.; Fagiolari, L.; Barbero, N.; Gerbaldi, C.; Bella, F.; Barolo, C. Recent advances in eco-friendly and cost-effective materials towards sustainable dye-sensitized solar cells. Green Chem. 2020, 22, 7168-7218. [CrossRef]

40. Pratiwi, D.; Nurosyid, F.; Supriyanto, A.; Suryana, R. Efficiency enhancement of dye-sensitized solar cells (DSSC) by addition of synthetic dye into natural dye (anthocyanin). IOP Conf. Ser. Mater. Sci. Eng. 2017, 176, 012012. [CrossRef]

41. Alhamed, M.; Issa, A.S.; Doubal, A.W. Studying of natural dyes properties as photo-sensitizer for dye sensitized solar cells (DSSC). J. Electr. Devices 2012, 16, 1370-1383.

42. Kumara, N.; Ekanayake, P.; Lim, A.; Liew, L.Y.C.; Iskandar, M.; Ming, L.C.; Senadeera, G. Layered co-sensitization for enhancement of conversion efficiency of natural dye sensitized solar cells. J. Alloys Compd. 2013, 581, 186-191. [CrossRef]

43. Wongcharee, K.; Meeyoo, V.; Chavadej, S. Dye-sensitized solar cell using natural dyes extracted from rosella and blue pea flowers Sol. Energy Mater. Sol. Cells 2007, 91, 566-571. [CrossRef]

44. Sakata, K.; Saito, N.; Honda, T. Ab initio study of molecular structures and excited states in anthocyanidins. Tetrahedron 2006, 62, 3721-3731. [CrossRef]

45. Mozaffari, S.A.; Saeidi, M.; Rahmanian, R. Photoelectric characterization of fabricated dye-sensitized solar cell using dye extracted from red Siahkooti fruit as natural sensitizer. Spectrochim. Acta Part A 2015, 142, 226-231. [CrossRef]

46. Luque, A.; Hegedus, S. Handbook of Photovoltaic Science and Engineering; John Wiley \& Sons: Hoboken, NJ, USA, 2011.

47. Hao, S.; Wu, J.; Huang, Y.; Lin, J. Natural dyes as photosensitizers for dye-sensitized solar cell. Sol. Energy 2006, 80, 209-214. [CrossRef]

48. Al-Alwani, M.A.; Mohamad, A.B.; Kadhum, A.A.H.; Ludin, N.A. Effect of solvents on the extraction of natural pigments and adsorption onto $\mathrm{TiO}_{2}$ for dye-sensitized solar cell applications. Spectrochim. Acta Part A 2015, 138, 130-137. [CrossRef]

49. Goswami, D.; Sinha, D.; De, D. Nanostructured ZnO and natural dye based DSSC for efficiency enhancement. In Proceedings of the 2017 Third International Conference on Science Technology Engineering \& Management, Chennai, India, 23-24 March 2017; pp. 556-560.

50. Marhuenda-Munoz, M.; Hurtado-Barroso, S.; Tresserra-Rimbau, A.; Lamuela-Raventos, R.M. A review of factors that affect carotenoid concentrations in human plasma: Differences between Mediterranean and Northern diets. Eur. J. Clin. Nutr. 2019, 72, 18-25. [CrossRef]

51. Bashar, H.; Bhuiyan, M.; Hossain, M.; Kabir, F.; Rahaman, M.; Manir, M.; Ikegami, T. Study on combination of natural red and green dyes to improve the power conversion efficiency of dye sensitized solar cells. Optik 2019, 185, 620-625. [CrossRef]

52. Kabir, F.; Sakib, S.N.; Matin, N. Stability study of natural green dye based DSSC. Optik 2019, 181, 458-464. [CrossRef]

53. Syafinar, R.; Gomesh, N.; Irwanto, M.; Fareq, M.; Irwan, Y. Chlorophyll pigments as nature based dye for dye-sensitized solar cell (DSSC). Energy Procedia 2015, 79, 896-902. [CrossRef]

54. Taya, S.A.; El-Agez, T.M.; El-Ghamri, H.S.; Abdel-Latif, M.S. Dye-sensitized solar cells using fresh and dried natural dyes. Int. J. Mater. Sci. Appl. 2013, 2, 37-42. [CrossRef] 
55. Ammar, A.M.; Mohamed, H.S.; Yousef, M.M.; Abdel-Hafez, G.M.; Hassanien, A.S.; Khalil, A.S. Dye-sensitized solar cells (DSSCs) based on extracted natural dyes. J. Nanomater. 2019, 2019, 1867271. [CrossRef]

56. Dinesh, V.; Sukhananazerin, A.; Sneha, J.M.; Kumar, P.M.; Biji, P. Novel stainless steel based, eco-friendly dye-sensitized solar cells using electrospun porous ZnO nanofibers. Nano Struct. Nano Objects 2019, 19, 100311. [CrossRef]

57. Chang, H.; Wu, H.M.; Chen, T.L.; Huang, K.D.; Jwo, C.S.; Lo, Y.J. Dye-sensitized solar cell using natural dyes extracted from spinach and ipomoea. J. Alloys Compd. 2010, 495, 606-610. [CrossRef]

58. Suyitno, S.; Saputra, T.J.; Supriyanto, A.; Arifin, Z. Stability and efficiency of dye-sensitized solar cells based on papaya-leaf dye. Spectrochim. Acta Part A 2015, 148, 99-104. [CrossRef]

59. Kumar, K.A.; Subalakshmi, K.; Senthilselvan, J. Effect of mixed valence state of titanium on reduced recombination for natural dye-sensitized solar cell applications. J. Solid State Electrochem. 2016, 20, 1921-1932. [CrossRef]

60. Adedokun, O.; Awodele, M.K.; Sanusi, Y.K.; Awodugba, A.O. Natural dye extracts from fruit peels as sensitizer in ZnO-based dye-sensitized solar cells. IOP Conf. Ser. Earth Environ. Sci. 2018, 173, 012040. [CrossRef]

61. Noor, M.; Buraidah, M.; Careem, M.; Majid, S.; Arof, A. An optimized poly (vinylidene fluoride-hexafluoropropylene)-NaI gel polymer electrolyte and its application in natural dye sensitized solar cells. Electrochim. Acta 2014, 121, 159-167. [CrossRef]

62. Diantoro, M.; Maftuha, D.; Suprayogi, T.; Iqbal, M.R.; Mufti, N.; Taufiq, A.; Hidayat, A.; Suryana, R.; Hidayat, R. Performance of pterocarpus indicus willd leaf extract as natural dye $\mathrm{TiO}_{2}$-Dye/ITO DSSC. Mater. Today Proc. 2019, 17, 1268-1276. [CrossRef]

63. Cari, C.; Khairuddin; Septiawan, T.; Suciatmoko, P.; Kurniawan, D.; Supriyanto, A. The preparation of natural dye for dyesensitized solar cell (DSSC). AIP Conf. Proc. 2018, 2014, 020106.

64. Sinha, D.; De, D.; Goswami, D.; Ayaz, A. Fabrication of DSSC with nanostructured ZnO photo anode and natural dye sensitizer. Mater. Today Proc. 2018, 5, 2056-2063. [CrossRef]

65. Maiaugree, W.; Lowpa, S.; Towannang, M.; Rutphonsan, P.; Tangtrakarn, A.; Pimanpang, S.; Maiaugree, P.; Ratchapolthavisin, N.; Sang-Aroon, W.; Jarernboon, W. A dye sensitized solar cell using natural counter electrode and natural dye derived from mangosteen peel waste. Sci. Rep. 2015, 5, 15230. [CrossRef]

66. Ali, R.A.M.; Nayan, N. Fabrication and analysis of dye-sensitized solar cell using natural dye extracted from dragon fruit. Int. J. Integr. Eng. 2010, 2, 55-62.

67. Surana, K.; Idris, M.G.; Bhattacharya, B. Natural dye extraction from Syzygium Cumini and its potential photovoltaic application as economical sensitizer. Appl. Nanosci. 2020, 10, 3819-3825. [CrossRef]

68. Singh, S.; Singh, P.K.; Kakroo, S.; Hachim, D.M.; Dhapola, P.S.; Khan, Z.H. Eco-friendly dye sensitized solar cell using natural dye with solid polymer electrolyte as hole transport material. Mater. Today Proc. 2021, 34, 760-766.

69. Maurya, I.C.; Singh, S.; Srivastava, P.; Maiti, B.; Bahadur, L. Natural dye extract from Cassia fistula and its application in dye-sensitized solar cell: Experimental and density functional theory studies. Opt. Mater. 2019, 90, 273-280. [CrossRef]

70. Kim, H.; Bin, Y.; Karthick, S.; Hemalatha, K.; Raj, C.J.; Venkatesan, S.; Park, S.; Vijayakumar, G. Natural dye extracted from Rhododendron species flowers as a photosensitizer in dye sensitized solar cell. Int. J. Electrochem. Sci. 2013, 8, 6734-6743.

71. Al-Alwani, M.A.; Hasan, H.A.; Al-Shorgani, N.K.N.; Al-Mashaan, A.B.S. Natural dye extracted from Areca catechu fruits as a new sensitiser for dye-sensitised solar cell fabrication: Optimisation using D-Optimal design. Mater. Chem. Phys. 2020, 240, 122204. [CrossRef]

72. Chawla, P.; Srivastava, A.; Tripathi, M. Performance of chitosan based polymer electrolyte for natural dye sensitized solar cell. Environ. Prog. Sustain. Energy 2019, 38, 630-634. [CrossRef]

73. Munawaroh, H.; Saputri, L.; Hanif, Q.; Hidayat, R.; Wahyuningsih, S. The co-pigmentation of anthocyanin isolated from mangosteen pericarp (Garcinia mangostana L.) as Natural Dye for Dye-Sensitized Solar Cells (DSSC). IOP Conf. Ser. Mater. Sci. Eng. 2016, 107, 012061. [CrossRef]

74. Ayalew, W.A.; Ayele, D.W. Dye-sensitized solar cells using natural dye as light-harvesting materials extracted from Acanthus sennii chiovenda flower and Euphorbia cotinifolia leaf. J. Sci. Adv. Mater. Devices 2016, 1, 488-494. [CrossRef]

75. Hamadanian, M.; Safaei-Ghomi, J.; Hosseinpour, M.; Masoomi, R.; Jabbari, V. Uses of new natural dye photosensitizers in fabrication of high potential dye-sensitized solar cells (DSSCs). Mater. Sci. Semicond. Process. 2014, 27, 733-739. [CrossRef]

76. Lim, A.; Ekanayake, P.; Lim, L.B.L.; Bandara, J.S. Co-dominant effect of selected natural dye sensitizers in DSSC performance. Spectrochim. Acta. Part A 2016, 167, 26-31. [CrossRef]

77. Teoli, F.; Lucioli, S.; Nota, P.; Frattarelli, A.; Matteocci, F.; Di Carlo, A.; Caboni, E.; Forni, C. Role of pH and pigment concentration for natural dye-sensitized solar cells treated with anthocyanin extracts of common fruits. J. Photochem. Photobiol. A 2016, 316, 24-30. [CrossRef]

78. Sathyajothi, S.; Jayavel, R.; Dhanemozhi, A.C. The fabrication of natural dye sensitized solar cell (DSSC) based on $\mathrm{TiO}_{2}$ using henna and beetroot dye extracts. Mater. Today Proc. 2017, 4, 668-676. [CrossRef]

79. Sinha, D.; De, D.; Ayaz, A. Photo sensitizing and electrochemical performance analysis of mixed natural dye and nanostructured ZnO based DSSC. Sādhanā 2020, 45, 175. [CrossRef]

80. Hossain, M.K.; Pervez, M.F.; Mia, M.; Mortuza, A.; Rahaman, M.; Karim, M.; Islam, J.M.; Ahmed, F.; Khan, M.A. Effect of dye extracting solvents and sensitization time on photovoltaic performance of natural dye sensitized solar cells. Results Phys. 2017, 7, 1516-1523. [CrossRef]

81. Ananth, S.; Vivek, P.; Arumanayagam, T.; Murugakoothan, P. Natural dye extract of lawsonia inermis seed as photo sensitizer for titanium dioxide based dye sensitized solar cells. Spectrochim. Acta Part A 2014, 128, 420-426. [CrossRef] 
82. Ruhane, T.; Islam, M.T.; Rahaman, M.S.; Bhuiyan, M.; Islam, J.M.; Bhuiyan, T.; Khan, K.; Khan, M.A. Impact of photo electrode thickness and annealing temperature on natural dye sensitized solar cell. Sustain. Energy Technol. Assess. 2017, $20,72-77$. [CrossRef]

83. Sultana, B.; Anwar, F.; Ashraf, M. Effect of extraction solvent/technique on the antioxidant activity of selected medicinal plant extracts. Molecules 2009, 14, 2167-2180. [CrossRef]

84. Euterpio, M.A.; Cavaliere, C.; Capriotti, A.L.; Crescenzi, C. Extending the applicability of pressurized hot water extraction to compounds exhibiting limited water solubility by $\mathrm{pH}$ control: Curcumin from the turmeric rhizome. Anal. Bioanal. Chem. 2011, 401, 2977-2985. [CrossRef]

85. Ruhane, T.A.; Islam, M.T.; Rahaman, M.S.; Bhuiyan, M.M.H.; Islam, J.M.M.; Newaz, M.K.; Khan, K.A.; Khan, M.A. Photo current enhancement of natural dye sensitized solar cell by optimizing dye extraction and its loading period. Optik 2017, 149, 174-183. [CrossRef]

86. Bredas, J.L.; Silbey, R.; Boudreaux, D.S.; Chance, R.R. Chain-length dependence of electronic and electrochemical properties of conjugated systems: Polyacetylene, polyphenylene, polythiophene, and polypyrrole. J. Am. Chem. Soc. 1983, 105, 6555-6559. [CrossRef]

87. Ashok Kumar, K.; Manonmani, J.; Senthilselvan, J. Effect on interfacial charge transfer resistance by hybrid co-sensitization in DSSC applications. J. Mater. Sci. Mater. Electron. 2014, 25, 5296-5301. [CrossRef]

88. Law, C.; Pathirana, S.C.; Li, X.; Anderson, A.Y.; Barnes, P.R.F.; Listorti, A.; Ghaddar, T.H.; O'Regan, B.C. Water-Based Electrolytes for Dye-Sensitized Solar Cells. Adv. Mater. 2010, 22, 4505-4509. [CrossRef]

89. Vaghasiya, J.V.; Nandakumar, D.K.; Yaoxin, Z.; Tan, S.C. Low toxicity environmentally friendly single component aqueous organic ionic conductors for high efficiency photoelectrochemical solar cells. J. Mater. Chem. A 2018, 6, 1009-1016. [CrossRef]

90. Bella, F.; Galliano, S.; Falco, M.; Viscardi, G.; Barolo, C.; Grätzel, M.; Gerbaldi, C. Unveiling iodine-based electrolytes chemistry in aqueous dye-sensitized solar cells. Chem. Sci. 2016, 7, 4880-4890. [CrossRef]

91. Click, K.A.; Schockman, B.M.; Dilenschneider, J.T.; McCulloch, W.D.; Garrett, B.R.; Yu, Y.; He, M.; Curtze, A.E.; Wu, Y. Bilayer dye protected aqueous photocathodes for tandem dye-sensitized solar cells. J. Phys. Chem. C 2017, 121, 8787-8795. [CrossRef]

92. Boldrini, C.L.; Manfredi, N.; Perna, F.M.; Trifiletti, V.; Capriati, V.; Abbotto, A. Dye-Sensitized Solar Cells that use an Aqueous Choline Chloride-Based Deep Eutectic Solvent as Effective Electrolyte Solution. Energy Technol. 2017, 5, 345-353. [CrossRef]

93. Galliano, S.; Bella, F.; Piana, G.; Giacona, G.; Viscardi, G.; Gerbaldi, C.; Grätzel, M.; Barolo, C. Finely tuning electrolytes and photoanodes in aqueous solar cells by experimental design. Sol. Energy 2018, 163, 251-255. [CrossRef]

94. Galliano, S.; Bella, F.; Gerbaldi, C.; Falco, M.; Viscardi, G.; Grätzel, M.; Barolo, C. Photoanode/electrolyte interface stability in aqueous dye-sensitized solar cells. Energy Technol. 2017, 5, 300-311. [CrossRef]

95. Fagiolari, L.; Bonomo, M.; Cognetti, A.; Meligrana, G.; Gerbaldi, C.; Barolo, C.; Bella, F. Photoanodes for Aqueous Solar Cells: Exploring Additives and Formulations Starting from a Commercial $\mathrm{TiO}_{2}$ Paste. ChemSusChem 2020, 13, 6562-6573. [CrossRef]

96. Bella, F.; Galliano, S.; Falco, M.; Viscardi, G.; Barolo, C.; Grätzel, M.; Gerbaldi, C. Approaching truly sustainable solar cells by the use of water and cellulose derivatives. Green Chem. 2017, 19, 1043-1051. [CrossRef]

97. Galliano, S.; Bella, F.; Bonomo, M.; Viscardi, G.; Gerbaldi, C.; Boschloo, G.; Barolo, C. Hydrogel Electrolytes Based on Xanthan Gum: Green Route towards Stable Dye-Sensitized Solar Cells. Nanomaterials 2020, 10, 1585. [CrossRef]

98. Galliano, S.; Bella, F.; Bonomo, M.; Giordano, F.; Grätzel, M.; Viscardi, G.; Hagfeldt, A.; Gerbaldi, C.; Barolo, C. Xanthan-Based Hydrogel for Stable and Efficient Quasi-Solid Truly Aqueous Dye-Sensitized Solar Cell with Cobalt Mediator. Sol. RRL 2021, 5, 2000823. [CrossRef]

99. Koo, H.-J.; Velev, O.D. Regenerable Photovoltaic Devices with a Hydrogel-Embedded Microvascular Network. Sci. Rep. 2013, 3, 2357. [CrossRef]

100. Kim, J.Y.; Kim, T.H.; Kim, D.Y.; Park, N.-G.; Ahn, K.-D. Novel thixotropic gel electrolytes based on dicationic bis-imidazolium salts for quasi-solid-state dye-sensitized solar cells. J. Power Sources 2008, 175, 692-697. [CrossRef]

101. Park, S.J.; Yoo, K.; Kim, J.-Y.; Kim, J.Y.; Lee, D.-K.; Kim, B.; Kim, H.; Kim, J.H.; Cho, J.; Ko, M.J. Water-Based Thixotropic Polymer Gel Electrolyte for Dye-Sensitized Solar Cells. ACS Nano 2013, 7, 4050-4056. [CrossRef]

102. De Haro, J.C.; Tatsi, E.; Fagiolari, L.; Bonomo, M.; Barolo, C.; Turri, S.; Bella, F.; Griffini, G. Lignin-Based Polymer Electrolyte Membranes for Sustainable Aqueous Dye-Sensitized Solar Cells. ACS Sustain. Chem. Eng. 2021, 9, 8550-8560. [CrossRef]

103. Yang, W.; Söderberg, M.; Eriksson, A.I.; Boschloo, G. Efficient aqueous dye-sensitized solar cell electrolytes based on a TEMPO/TEMPO ${ }^{+}$redox couple. RSC Adv. 2015, 5, 26706-26709. [CrossRef]

104. Lee, Y.-L.; Chang, C.-H. Efficient polysulfide electrolyte for CdS quantum dot-sensitized solar cells. J. Power Sources 2008, 185, 584-588. [CrossRef]

105. Kamenan, K.A.; Jagadeesh, A.; Assanvo, E.F.; Soman, S.; Unni, K.N. Natural rubber (Hevea Brasiliensis)-based quasi-solid electrolyte as a potential candidate for arresting recombination and improving performance in aqueous dye-sensitized solar cells. J. Mater. Sci. Mater. Electron. 2021, 32, 14207-14216. [CrossRef]

106. Choi, H.; Jeong, B.-S.; Do, K.; Ju, M.J.; Song, K.; Ko, J. Aqueous electrolyte based dye-sensitized solar cells using organic sensitizers. New J. Chem. 2013, 37, 329-336. [CrossRef]

107. Zhang, H.; Qiu, L.; Xu, D.; Zhang, W.; Yan, F. Performance enhancement for water based dye-sensitized solar cells via addition of ionic surfactants. J. Mater. Chem. A 2014, 2, 2221-2226. [CrossRef] 
108. Fayad, R.; Shoker, T.A.; Ghaddar, T.H. High photo-currents with a zwitterionic thiocyanate-free dye in aqueous-based dye sensitized solar cells. Dalton Trans. 2016, 45, 5622-5628. [CrossRef]

109. Kato, R.; Kato, F.; Oyaizu, K.; Nishide, H. Redox-active hydroxy-TEMPO radical immobilized in Nafion layer for an aqueous electrolyte-based and dye-sensitized solar cell. Chem. Lett. 2014, 43, 480-482. [CrossRef]

110. Suzuka, M.; Hara, S.; Sekiguchi, T.; Oyaizu, K.; Nishide, H. Polyviologen as the charge-storage electrode of an aqueous electrolyte-and organic-based dye-sensitized solar cell. Polymer 2015, 68, 353-357. [CrossRef]

111. Leandri, V.; Ellis, H.; Gabrielsson, E.; Sun, L.; Boschloo, G.; Hagfeldt, A. An organic hydrophilic dye for water-based dye-sensitized solar cells. Phys. Chem. Chem. Phys. 2014, 16, 19964-19971. [CrossRef]

112. Sonigara, K.K.; Vaghasiya, J.V.; Machhi, H.K.; Prasad, J.; Gibaud, A.; Soni, S.S. Anisotropic One-Dimensional Aqueous Polymer Gel Electrolyte for Photoelectrochemical Devices: Improvement in Hydrophobic $\mathrm{TiO}_{2}-\mathrm{Dye} /$ Electrolyte Interface. ACS Appl. Energy Mater. 2018, 1, 3665-3673. [CrossRef]

113. Yogananda, K.; Ramasamy, E.; Kumar, S.; Kumar, S.V.; Rani, M.N.; Rangappa, D. Novel rice starch based aqueous gel electrolyte for dye sensitized solar cell application. Mater. Today Proc. 2017, 4, 12238-12244. [CrossRef]

114. Saito, H.; Uegusa, S.; Murakami, T.N.; Kawashima, N.; Miyasaka, T. Fabrication and efficiency enhancement of water-based dye-sensitized solar cells by interfacial activation of $\mathrm{TiO}_{2}$ mesopores. Electrochemistry 2004, 72, 310-316. [CrossRef]

115. Murakami, T.N.; Saito, H.; Uegusa, S.; Kawashima, N.; Miyasaka, T. Water-based dye-sensitized solar cells: Interfacial activation of $\mathrm{TiO}_{2}$ mesopores in contact with aqueous electrolyte for efficiency development. Chem. Lett. 2003, 32, 1154-1155. [CrossRef]

116. Bella, F.; Galliano, S.; Piana, G.; Giacona, G.; Viscardi, G.; Grätzel, M.; Barolo, C.; Gerbaldi, C. Boosting the efficiency of aqueous solar cells: A photoelectrochemical estimation on the effectiveness of $\mathrm{TiCl}_{4}$ treatment. Electrochim. Acta 2019, 302, 31-37. [CrossRef]

117. Pham, B.; Willinger, D.; McMillan, N.K.; Roye, J.; Burnett, W.; D’Achille, A.; Coffer, J.L.; Sherman, B.D. Tin (IV) oxide nanoparticulate films for aqueous dye-sensitized solar cells. Sol. Energy 2021, 224, 984-991. [CrossRef]

118. Kim, J.-H.; Park, S.-Y.; Lim, D.-H.; Lim, S.-Y.; Choi, J.; Koo, H.-J. Eco-Friendly Dye-Sensitized Solar Cells Based on WaterElectrolytes and Chlorophyll. Materials 2021, 14, 2150. [CrossRef]

119. Kang, T.-S.; Chun, K.-H.; Hong, J.S.; Moon, S.-H.; Kim, K.-J. Enhanced Stability of Photocurrent-Voltage Curves in Ru(II)-DyeSensitized Nanocrystalline $\mathrm{TiO}_{2}$ Electrodes with Carboxylic Acids. J. Electrochem. Soc. 2000, 147, 3049. [CrossRef]

120. Lu, H.-L.; Lee, Y.-H.; Huang, S.-T.; Su, C.; Yang, T.C.K. Influences of water in bis-benzimidazole-derivative electrolyte additives to the degradation of the dye-sensitized solar cells. Sol. Energy Mater. Sol. Cells 2011, 95, 158-162. [CrossRef]

121. Macht, B.; Turrion, M.; Barkschat, A.; Salvador, P.; Ellmer, K.; Tributsch, H. Patterns of efficiency and degradation in dye sensitization solar cells measured with imaging techniques. Sol. Energy Mater. Sol. Cells 2002, 73, 163-173. [CrossRef]

122. Jung, Y.-S.; Yoo, B.; Lim, M.K.; Lee, S.Y.; Kim, K.-J. Effect of Triton X-100 in water-added electrolytes on the performance of dye-sensitized solar cells. Electrochim. Acta 2009, 54, 6286-6291. [CrossRef]

123. Weidmann, J.; Dittrich, T.; Konstantinova, E.; Lauermann, I.; Uhlendorf, I.; Koch, F. Influence of oxygen and water related surface defects on the dye sensitized $\mathrm{TiO}_{2}$ solar cell. Sol. Energy Mater. Sol. Cells 1999, 56, 153-165. [CrossRef]

124. Liu, Y.; Hagfeldt, A.; Xiao, X.-R.; Lindquist, S.-E. Investigation of influence of redox species on the interfacial energetics of a dye-sensitized nanoporous $\mathrm{TiO}_{2}$ solar cell. Sol. Energy Mater. Sol. Cells 1998, 55, 267-281. [CrossRef]

125. Zhang, Z.; Chen, P.; Murakami, T.N.; Zakeeruddin, S.M.; Grätzel, M. The 2,2,6,6-tetramethyl-1-piperidinyloxy radical: An efficient, iodine-free redox mediator for dye-sensitized solar cells. Adv. Funct. Mater. 2008, 18, 341-346. [CrossRef]

126. Yang, W.; Vlachopoulos, N.; Hao, Y.; Hagfeldt, A.; Boschloo, G. Efficient dye regeneration at low driving force achieved in triphenylamine dye LEG4 and TEMPO redox mediator based dye-sensitized solar cells. Phys. Chem. Chem. Phys. 2015, 17, 15868-15875. [CrossRef]

127. Choi, H.; Han, J.; Kang, M.-S.; Song, K.; Ko, J. Aqueous Electrolytes Based Dye-sensitized Solar Cells using $\mathrm{I}^{-} / \mathrm{I}_{3}{ }^{-}$Redox Couple to Achieve $\geq 4 \%$ Power Conversion Efficiency. Bull. Korean Chem. Soc. 2014, 35, 1433-1439. [CrossRef]

128. Law, C.; Moudam, O.; Villarroya-Lidon, S.; O’Regan, B. Managing wetting behavior and collection efficiency in photoelectrochemical devices based on water electrolytes; improvement in efficiency of water/iodide dye sensitised cells to $4 \%$. J. Mater. Chem. 2012, 22, 23387-23394. [CrossRef]

129. Meen, T.-H.; Jhuo, Y.-T.; Chao, S.-M.; Lin, N.-Y.; Ji, L.-W.; Tsai, J.-K.; Wu, T.-C.; Chen, W.-R.; Water, W.; Huang, C.-J. Effect of TiO 2 nanotubes with $\mathrm{TiCl}_{4}$ treatment on the photoelectrode of dye-sensitized solar cells. Nanoscale Res. Lett. 2012, 7, 579. [CrossRef]

130. Lee, S.-W.; Ahn, K.-S.; Zhu, K.; Neale, N.R.; Frank, A.J. Effects of $\mathrm{TiCl}_{4}$ treatment of nanoporous $\mathrm{TiO}_{2}$ films on morphology, light harvesting, and charge-carrier dynamics in dye-sensitized solar cells. J. Phys. Chem. C 2012, 116, 21285-21290. [CrossRef]

131. Sommeling, P.; O’Regan, B.C.; Haswell, R.; Smit, H.; Bakker, N.; Smits, J.; Kroon, J.M.; Van Roosmalen, J. Influence of a TiCl 4 post-treatment on nanocrystalline $\mathrm{TiO}_{2}$ films in dye-sensitized solar cells. J. Phys. Chem. B 2006, 110, 19191-19197. [CrossRef]

132. O'Regan, B.C.; Durrant, J.R.; Sommeling, P.M.; Bakker, N.J. Influence of the $\mathrm{TiCl}_{4}$ treatment on nanocrystalline $\mathrm{TiO}_{2}$ films in dye-sensitized solar cells. 2. Charge density, band edge shifts, and quantification of recombination losses at short circuit. J. Phys. Chem. C 2007, 111, 14001-14010. [CrossRef]

133. Salgado-Castro, K.; Lijanova, I.V.; Jaramillo-Vigueras, D.; Castillo-Cervantes, J.N. Effect of the $\mathrm{TiO}_{2}$ Anchoring of a Hydrophobic Ionic Liquid in a Fully Aqueous DSSC. IEEE J. Photovolt. 2019, 9, 1708-1715. [CrossRef]

134. Gu, P.; Yang, D.; Zhu, X.; Sun, H.; Wangyang, P.; Li, J.; Tian, H. Influence of electrolyte proportion on the performance of dye-sensitized solar cells. AIP Adv. 2017, 7, 105219. [CrossRef] 
135. Lai, W.H.; Su, Y.H.; Teoh, L.G.; Hon, M.H. Commercial and natural dyes as photosensitizers for a water-based dye-sensitized solar cell loaded with gold nanoparticles. J. Photochem. Photobiol. A 2008, 195, 307-313. [CrossRef]

136. Kokal, R.K.; Bhattacharya, S.; Cardoso, L.S.; Miranda, P.B.; Soma, V.R.; Chetti, P.; Melepurath, D.; Raavi, S.S.K. Low cost 'green'dye sensitized solar cells based on New Fuchsin dye with aqueous electrolyte and platinum-free counter electrodes. Sol. Energy 2019, 188, 913-923. [CrossRef] 